OPEN ACCESS

Edited by:

Sarah M Temkin,

National Institutes of Health $(\mathrm{NIH})$,

United States

Reviewed by:

Dong-Joo (Ellen) Cheon, Albany Medical College, United States Dinesh Ahirwar.

The Ohio State University,

United States

*Correspondence:

Snehasikta Swarnakar snehasiktaiicbidi@gmail.com

${ }^{\dagger}$ These authors have contributed equally to this work and share first authorship

Specialty section:

This article was submitted to Gynecological Oncology,

a section of the journal

Frontiers in Oncology

Received: 04 June 2021 Accepted: 30 December 2021

Published: 25 January 2022

Citation:

Pandit A, Begum Y, Saha P, Srivastava AK and Swarnakar S (2022) Approaches Toward Targeting Matrix Metalloproteases for Prognosis and Therapies in Gynecological Cancer: MicroRNAs as a Molecular Driver.

Front. Oncol. 11:720622. doi: 10.3389/fonc.2021.720622

\section{Approaches Toward Targeting Matrix Metalloproteases for Prognosis and Therapies in Gynecological Cancer: MicroRNAs as a Molecular Driver}

\author{
Anuradha Pandit ${ }^{1 \dagger}$, Yasmin Begum ${ }^{1 \dagger}$, Priyanka Saha ${ }^{2}$, Amit Kumar Srivastava ${ }^{2}$ \\ and Snehasikta Swarnakar ${ }^{1 *}$ \\ 1 Infectious Diseases \& Immunology Division, CSIR-Indian Institute of Chemical Biology, Kolkata, India, ${ }^{2}$ Cancer Biology \& \\ Inflammatory Disorder Division, CSIR-Indian Institute of Chemical Biology, Kolkata, India
}

Gene expression can be regulated by small non-coding RNA molecules like microRNAs (miRNAs) which act as cellular mediators necessary for growth, differentiation, proliferation, apoptosis, and metabolism. miRNA deregulation is often observed in many human malignancies, acting both as tumor-promoting and suppressing, and their abnormal expression is linked to unrestrained cellular proliferation, metastasis, and perturbation in DNA damage as well as cell cycle. Matrix Metalloproteases (MMPs) have crucial roles in both growth, and tissue remodeling in normal conditions, as well as in promoting cancer development and metastasis. Herein, we outline an integrated interactive study involving various MMPs and miRNAs and also feature a way in which these communications impact malignant growth, movement, and metastasis. The present review emphasizes on important miRNAs that might impact gynecological cancer progression directly or indirectly via regulating MMPs. Additionally, we address the likely use of miRNA-mediated MMP regulation and their downstream signaling pathways towards the development of a potential treatment of gynecological cancers.

Keywords: microRNA, gynecological cancer, matrix metalloprotease (MMP), EMT, metastasis

\section{BACKGROUND}

Gynecological malignancies, like cervical, ovarian, and endometrial cancers, account significantly for most of the global cancer load, where cervical cancer (CC) accounts to be the fourth most prevalent malignancy among women, along with ovarian cancer (OC) comprising $4.4 \%$ of the entire cancerrelated mortality among women (1). In 2018, endometrial cancer (EC) was reported to have caused 382,069 cases and 89,929 deaths globally (1). The percentage of women over 65 diagnosed with cancer is projected to increase dramatically over the next decade (2). As a result, there is already a significant unmet therapeutic need in the field for successful treatments of gynecological malignancies.

Gynecological cancers have a high mortality rate due to the diagnosis at late stages in addition to multi-drug resistance, impaired apoptotic pathway, inhibition of the immune system, and aberrant

Abbreviations: miRNAs, microRNAs; MMP, matrix metalloprotease; ECM, extracellular matrix; CC, cervical cancer; OC, ovarian cancer; EOC, epithelial ovarian cancer; EMT, epithelial-mesenchymal transition; AGO, Argonaute. 
MMP production $(3,4)$. Extracellular matrix (ECM) remodeling is crucial for maintaining extracellular microenvironment homeostasis and tissue turnover. Tumor cells must be able to disrupt the surrounding ECM to proliferate, invade, and metastasize. Uncontrolled tumor proliferation, tissue remodeling, inflammation, cellular invasion, and metastasis are all consequences of abnormal ECM proteolysis. Matrix metalloproteases (MMPs) are enzymes capable of degrading multiple ECM components, leading to wound healing, tissue repair, embryonic development (5). Rampant MMP expression has been associated with tumor aggressiveness, metastasis, and vascularization and is correlated with late diagnosis in various malignancies such as lung, prostate, colon, breast, and pancreatic cancers (6-10). MMP expression is closely monitored by many regulatory mechanisms, which include zymogen activation, compartmentalization, endogenously produced tissue inhibitors of metalloproteases (TIMPs), and miRNAs.

miRNAs are endogenously produced non-coding RNA elements responsible for gene silencing by degrading target mRNA. They are frequently altered during tumorigenesis and their ability to regulate various genes has made them an attractive candidate for cancer therapeutics (11). Dysregulation of both MMP and miRNA levels is a pronounced feature of gynecological cancers (12-14). The involvement of miRNAs to regulate the expression of the MMP gene has recently received a lot of attention. MMP regulation by various miRNAs may affect cancer progression. Moreover, the functional relevance of miRNA-mediated MMP regulation in malignancies might be explored further by examining the post-transcriptional regulation system controlling MMP gene expression. The current study focuses on the mechanisms controlling MMP expression by miRNAs in gynecological cancers and also aims to come up with a strategy to assist miRNAs targeting MMPs for diagnosis and therapeutic intervention.

\section{MIRNA BIOGENESIS}

Numerous small RNAs have been evolved to negatively regulate undesired genetic elements and transcripts (15). miRNAs are the most dominating group of small RNAs having a length of $\sim 22$ nucleotides and are generated by RNase III proteins namely Dicer and Drosha (16). miRNA functions as a guide by targeting specific mRNAs at its 3'untranslated region (3'UTR) region usually by base-pairing thereby inducing RNA silencing (17) and AGO proteins act as the effector proteins recruiting factors that induce mRNA deadenylation, translational repression, and mRNA degradation (18).

Because each miRNA affects a vast number of mRNAs, the miRNA biogenesis pathway has a pivotal role in gene regulation as well as their networks. Throughout the last decade, miRNAs have been revealed to play important roles in tumor cell recruitment, progression, and metastasis (19). The miR 17-92 cluster expression, which cooperated with MYC to induce cancer growth in a B cell lymphoma mouse model, was the very first example (20). Certain miRNA also functions as tumor suppressors, for instance, the let 7 family suppresses tumor development and metastasis via targeting key oncogenic genes like high-mobility group AT-hook 2 (HMGA2), members of the RAS family (NRAS, KRAS, and HRAS), and MYC (21-23). As a result, cancer-related variations in the expression profiles of miRNA are emerging as promising diagnostic markers as well as the targets, for therapeutics, that are frequently linked to tumor growth and overall survival (19). Although particular miRNAs possess either an oncogenic or tumor-suppressive effect, multiple reports suggested a decreased miRNA expression universally in cancerous cells in contrast to healthy cells, implying that miRNA synthesis may be disrupted during tumorigenesis $(24,25)$.

Most of the miRNA genes are transcribed as pri-miRNA, made up of a hairpin loop structure which consists of a sequence of miRNA, by RNA polymerase II (Pol II) either as intronic clusters in the pre-mRNAs or as individual genetic elements, encoded within long non-coding RNAs (26). The biogenesis of miRNAs is carried out in two steps, first processed inside the nuclei and then in the cytoplasm $(26,27)$. DROSHA, an RNase type III enzyme, along with other related proteins comprises the microprocessor complex which catalyzes the nuclear event (26). This nuclear processing event leads to the synthesis of premiRNAs, which are $\sim 70$ nucleotides stem-loop-like precursor miRNAs that are then exported to the cytosol through the Exportin-5 (XPO-5) export receptor (28). The pre-miRNAs are later catalyzed in the cytosol by DICER, another RNase type III enzyme, which leads to miRNA duplex formation. These miRNA duplexes are then incorporated into RISC (RNA-Induced Silencing complex) along with another protein namely Argonaute (AGO), where only a single strand is chosen to form the mature miRNA (Figure 1) (29).

Also, there is a non-canonical miRNA biogenesis pathway that also produces functional miRNAs. Such as mirtrons which are produced through the pre-mRNA splicing process, while certain other miRNAs are produced from small nucleolar RNA (snoRNA) precursors, $\mathrm{m}^{7} \mathrm{G}$ pre-miRNA/Exportin 1 pathway, $\mathrm{t}$ RNA derived pathway, etc (16). Mirtrons are miRNAs, a byproduct of intron splicing, made by a non-canonical route that skips the Drosha cleavage step. Mirtrons go through lariatdebranching by DBR1, a debranching enzyme, then enter the conventional route at the exportin-5 level, therefore known as canonical mirtrons (Figure 1) (30).

Phosphorylation, ubiquitination, and sumoylation are some of the post-translational modifications of miRNA processing factors that can influence DGCR8, DROSHA, and/or DICER complex components. In another report, it was revealed that the regulation of miRNA biogenesis can also happen in a cell density-dependent manner (26).

\section{ROLE OF MMPS IN CANCER}

MMPs are endopeptidases monitoring ECM's physiological turnover and remodeling. While collagens, gelatins, proteoglycans, and elastin are among their substrates, they 


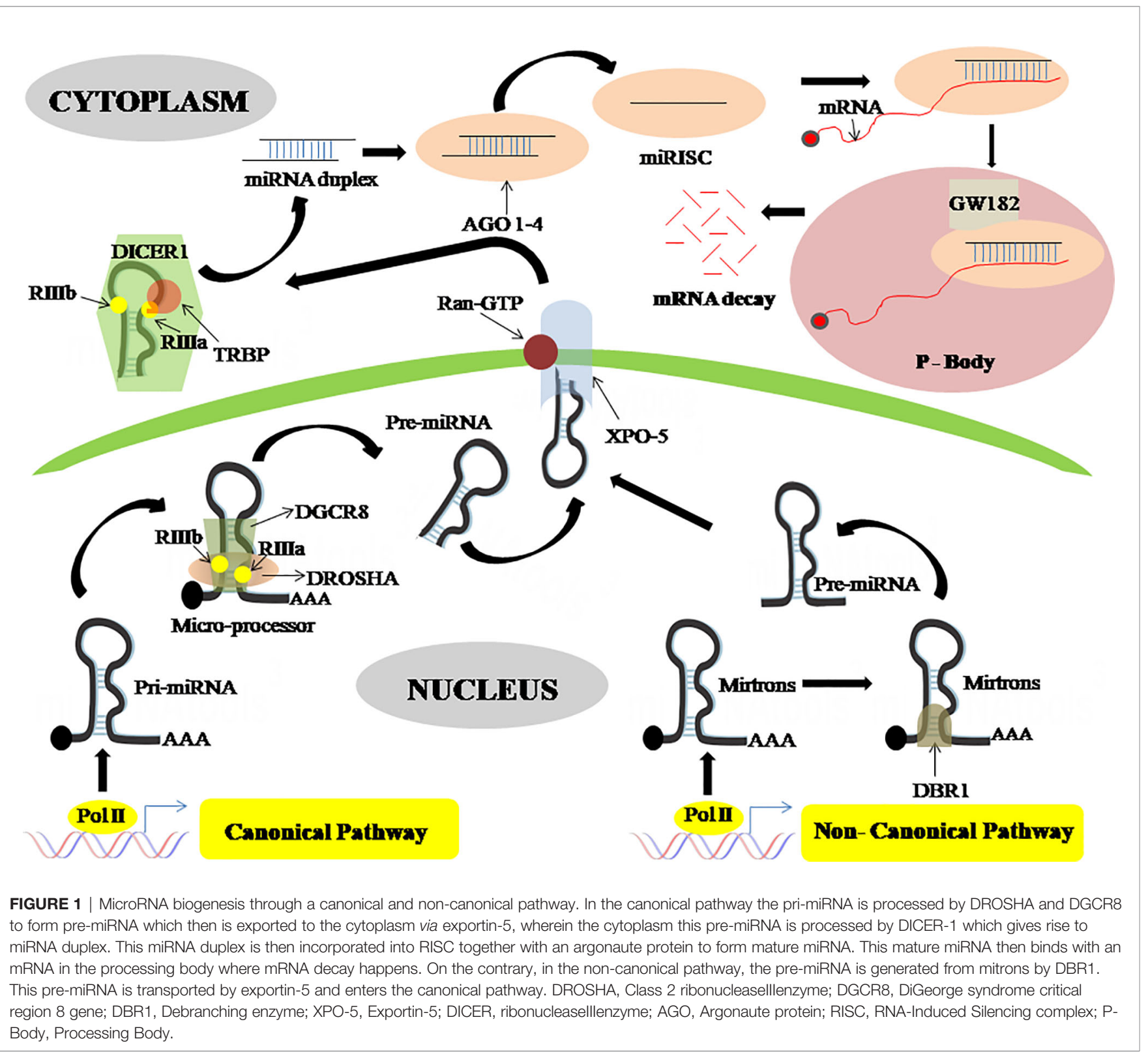

have a wide range of effects on many other proteins (31). Because MMPs digest a diverse array of substrates, their actions have a major impact on the extracellular environment, and if left uncontrolled, can lead to unnecessary ECM degradation (32, 33). MMPs consist of a predomain, catalytic domain, hemopexin domain and prodomain. MMPs are secreted as pro-enzymes, which are made inactive by interacting with a cysteinesulphydryl group in the N-terminal (pro) domain with the zinc ion in the catalytic domain. The elimination of this association is known as the "cysteine switch," and it is triggered by prohormone convertases (furin) (34). Another level of MMP regulation is performed by TIMPs that bind to the MMP catalytic site and regulate proteolytic activity. Nonspecific antagonists such as 2-macroglobulin, thrombospondin-1, and
-2 can also inhibit MMPs (35). MMPs are divided into Collagenases, Gelatinases, Stromelysins, Matrilysin and membrane-type and non-classified MMPs subtypes. MMPs are crucial in the biochemical interplay between tumor and stroma. Stromal cells produce the majority of MMPs in the tumor microenvironment, bringing about ECM cleavage, thereby forming a path for cell movement from the tumor niche into adjoining areas and also releasing several bioactive compounds. Interaction of tumor cells with neighboring stromal cells is critical in facilitating cancer initiation and progression. Tumor cells secrete growth factors such as VEGF, EGF, FGF, interleukins, and IFN, which stimulate surrounding cells in the tumor tissues to release MMPs, allowing tumor cells to migrate $(36,37)$. 


\section{MMPs in Cell Growth}

Cancer cells are known for their uncontrolled proliferation. The tumor reaches this state in one of two ways: by being selfsufficient in growth-promoting signals or developing immunity to antigrowth signals. Cellular proliferation can be unchecked as a result of MMPs cleaving growth factor binding proteins, increasing their bioavailability, or activating growth factor receptors $(38,39)$. TGF- $\beta$ It is activated by proteases like MMP-9, -2, - 14, which leads to increased invasion and metastasis (40, 41). MMP-1 is found in stromal and epithelial cancer cells of invasive carcinomas and regulates cervical tumorigenesis and lymph node metastasis via the PPAR signaling pathway $(42,43)$. MMP-7 is implicated in cell proliferation, migration, and invasion, possibly through the wnt/catenin pathway $(44,45)$. Activation of the PKC pathway led to an increase in MMP-7 and 10 in cancer cells, indicating their involvement in cell proliferation and migration in OC (46). MMP-2 was shown to participate in OC cell proliferation via p38/MAPK pathway (47).

\section{MMPs in Apoptosis}

Fas ligand binds to extracellular receptors like Fas receptors and activates intracellular caspases, resulting in the degradation of subcellular compartments, thus halting malignant spread. MMP activity inhibits apoptosis in malignant cells, by cleaving proapoptotic ligands or receptors (48).In human OC cells, downregulation of MMP-9 was shown to induce apoptosis and prevent proliferation (49). In another study, MMP-2 increased cell proliferation and reduced apoptosis in OVCAR3 (ovarian cancer cell line) cells, thereby lowering the effect of chemotherapeutic drugs on tumor cells (50).

\section{MMPs in Invasion and Metastasis}

The tumor cells will subsequently enter the circulation and spread throughout the body by modulating MMP production (51). MMP-2 and -9 are the most prominent MMPs modulating cancer cell invasion. In both OC and CC, MMP-2 and -9 are implicated in cancer cell invasion and metastasis and are associated with poor survival $(52,53)$. Furthermore, MMP-2 promotes the attachment of metastatic OC cells to peritoneal surfaces by cleaving ECM and increasing their binding to integrin, as well as the OC cells' propensity to metastasize (54). Similarly, in CC, an association of MMP-2 activation with $\alpha \mathrm{v} \beta 3$ integrin/MT1MMP/TIMP-2 has been implicated in tumor cell migration (55). MMP-7 is the primary MMP linked with invasion and metastasis in EC (56). MMP-7 is also overexpressed in ovarian serous cancer tissues, where it increases cellular invasiveness by activating MMP2 and -9 or by IGFBP breakdown, enhancing IGF concentration and cancer cell proliferation $(57,58)$.

\section{MMPs in Angiogenesis}

The role of MMPs in angiogenesis is dependent on the neighboring environment, such as substrate abundance and MMP expression time points during angiogenesis (59). MMP-2 is a widely known influencer of vascularization during cancer development. In OC, MMP-2 expression was increased via PI3K/
Akt and NFאB pathways, enhancing endothelial progenitor cell proliferation (60). Activation of PAR-1 via MMP-1 causes OC cells to secrete multiple angiogenic factors, resulting in cell proliferation, endothelial tube formation, and migration (61, 62). MMP-9 has a role in the release of VEGF from tumors (63). OC cells implanted into $\mathrm{Mmp9}^{-/-}$nude mice showed significantly lower levels of VEGF in tumors, thereby contributing to angiogenesis (64).

\section{REGULATION OF MMPs BY miRNAs}

Considerable interest is seen in investigating post-transcriptional regulations of MMPs by miRNAs in recent times. Bioinformatics analyses have identified several miRNAs binding sites at the 3'UTR of MMP transcripts, thereby inducing mRNA instability or translational repression $(11,65)$. Studies have shown the participation of miRNA in regulating MMP gene expression thereby playing a key role in migration, differentiation, apoptosis, etc (66-68). These miRNAs either promote or repress malignant phenotype, acting as either oncogenic or tumorsuppressor, respectively. Oncogenic miRNAs (OncomiRs) are overexpressed in cancers whereas tumor-suppressor miRNA is downregulated, thereby leading to the onset of carcinogenesis, metastasis, and poor survival. However, there are conflicting pieces of evidence as if a miRNA behaves like an oncogene or tumor-suppressor in the tumor microenvironment. This review wishes to directly examine the effects of miRNAs towards MMP regulation in gynecological cancer development and disease progression (Table 1).

\section{OncomiRs}

Several oncogenic miRNAs were found to be linked with gynecological cancer development and are involved in cell migration, angiogenesis, apoptosis, etc. $(73,78)$. Each miRNA has many different targets and modulate different signaling pathways in different cancer types $(75,99)$. The endogenous inhibitors of MMPs are known as tissue inhibitors of matrix metalloproteases (TIMPs). Disruption of MMPs/TIMPs balance occurs during multiple pathological conditions including cancer. In CC, miR-106a downregulates TIMP-2 through direct binding to its 3'-UTR region resulting in the induction of MMP-2 as well as MMP-9 expression and subsequently promoting cellular invasion, and migration (69). Alteration of TIMP-2 expression partly eradicates the invasion, migration, and MMP-2/9 expression in CC cells (34). Similarly, in HPV-induced CC, miR-21down-regulates TIMP-3, PTEN, and STAT3 expressions (61). Additionally, in uterine endometrial stromal sarcoma, miR21 decreases the level of PTEN by directly binding to 3'UTR, leading to increased proliferation, invasion, decreased apoptosis, and metastatic potential thereby upregulating MMP-2 and -9 (73, 78). Epithelial-to-mesenchymal transition (EMT) is a crucial feature of cancer enabling cells to acquire mobility and translocate to distant sites. miR-183 promotes cellular proliferation and EMT in uterine EC by inhibiting CPEB1 expression and up-regulating MMP-9 expression. Studies 
TABLE 1 | Oncogenic and tumor suppressor miRNAs regulating MMPs during development of gynecological cancers.

\begin{tabular}{|c|c|c|c|c|c|c|}
\hline Disease & microRNA & ExpressionLevel & $\begin{array}{l}\text { MMPs } \\
\text { Involved }\end{array}$ & Binding & Function(s) & References \\
\hline Cervical Cancer & $\begin{array}{l}\text { miR-1246 } \\
\text { miR-106a } \\
\text { miR-183 } \\
\text { miR200b }\end{array}$ & $\begin{array}{l}\text { Upregulated } \\
\text { Upregulated } \\
\text { Downregulated } \\
\text { Downregulated }\end{array}$ & $2 / 9$ & $\begin{array}{l}\text { Indirect } \\
\text { Indirect } \\
\text { Direct } \\
\text { Indirect }\end{array}$ & $\begin{array}{l}\text { Induces proliferation, tumor growth, cell migration, invasion, metastasis } \\
\text { and EMT. }\end{array}$ & $(69-72)$ \\
\hline Cervical Cancer & $\operatorname{miR}-21$ & Upregulated & $2 / 9$ & Indirect & $\begin{array}{l}\text { Increased STAT3 decreased TIMP-3 and PTEN expression leading to } \\
\text { cell invasion. }\end{array}$ & $(73)$ \\
\hline Cervical Cancer & $\begin{array}{l}\operatorname{miR}-195- \\
5 p\end{array}$ & Downregulated & 14 & Direct & $\begin{array}{l}\text { Promotes proliferation and invasion by directly binding of miR-195-5p to } \\
\text { 3'UTR of MMP-14 and modulating TNF- } \alpha \text { pathway }\end{array}$ & $(74)$ \\
\hline Endometrial Cancer & $\begin{array}{l}\mathrm{miR}-183 \\
\mathrm{miR}-130 \mathrm{~b}\end{array}$ & $\begin{array}{l}\text { Upregulated } \\
\text { Upregulated }\end{array}$ & $2 / 9$ & $\begin{array}{l}\text { Direct } \\
\text { Indirect }\end{array}$ & Promotes cell proliferation and invasion. & $(75-77)$ \\
\hline $\begin{array}{l}\text { Uterine Endometrial } \\
\text { Stromal Carcinoma }\end{array}$ & $\begin{array}{l}\text { miR-21 } \\
\text { miR-31 } \\
\text { miR-145 } \\
\text { miR-195 }\end{array}$ & $\begin{array}{l}\text { Upregulated } \\
\text { Downregulated } \\
\text { Upregulated } \\
\text { Upregulated }\end{array}$ & 2 & $\begin{array}{l}\text { Indirect } \\
\text { Indirect } \\
\text { Indirect } \\
\text { Indirect }\end{array}$ & Induces cell invasion and wound healing. & $(78)$ \\
\hline Ovarian Cancer & $\begin{array}{l}\operatorname{miR}-92 \\
\mathrm{miR}-210\end{array}$ & $\begin{array}{l}\text { Upregulated } \\
\text { Upregulated }\end{array}$ & $2 / 9$ & $\begin{array}{l}\text { Indirect } \\
\text { Indirect }\end{array}$ & $\begin{array}{l}\text { Promotes migration and angiogenesis by inhibiting } \mathrm{VHL} \text { and upregulating } \\
\mathrm{HIF} 1 \alpha \text { pathway genes. }\end{array}$ & $(79,80)$ \\
\hline Ovarian Cancer & miR-205 & Upregulated & $2 / 10$ & Indirect & Promotes invasion via inhibiting TCF-21. & $(81)$ \\
\hline $\begin{array}{l}\text { Endometrial } \\
\text { Adenocarcinoma }\end{array}$ & $\operatorname{miR}-410$ & Downregulated & 14 & Direct & Promotes tumor formation. & $(13,82)$ \\
\hline Endometrial Cancer & miR-195 & Downregulated & $2 / 9$ & Indirect & Promotes EMT by targeting GPER/PI3K/AKT. & (83) \\
\hline $\begin{array}{l}\text { Endometrial } \\
\text { Endometroid } \\
\text { Carcinoma }\end{array}$ & mir-22 & Downregulated & $2 / 9$ & Indirect & Induces cell proliferation and invasion. & $(84)$ \\
\hline Endometrial Cancer & $\begin{array}{l}\text { miR-320a } \\
\text { miR-340- } \\
5 p\end{array}$ & $\begin{array}{l}\text { Downregulated } \\
\text { Downregulated }\end{array}$ & $3 / 9$ & $\begin{array}{l}\text { Indirect } \\
\text { Indirect }\end{array}$ & Inhibits TGF $\beta$-induced EMT. & $(85)$ \\
\hline Ovarian Cancer & $\begin{array}{l}\operatorname{miR}-574- \\
3 p\end{array}$ & Downregulated & 9 & Indirect & $\begin{array}{l}\text { Promotes migration and invasion, inhibiting AKT, FAK and c-Src by } \\
\text { targeting EGFR. }\end{array}$ & $(86)$ \\
\hline Ovarian Cancer & $\mathrm{miR}-29 \mathrm{~b}$ & Downregulated & 2 & Direct & $\begin{array}{l}\text { Induces cell migration by regulating crosstalk between OC cells and } \\
\text { fibroblast. }\end{array}$ & $(12,87)$ \\
\hline Ovarian Cancer & $\begin{array}{l}\operatorname{miR}-1236- \\
3 p\end{array}$ & Downregulated & 2 & Indirect & Promotes proliferation and invasion and EMT via VEGF. & (88) \\
\hline Ovarian Cancer & $\mathrm{miR}-16$ & Downregulated & $2 / 9$ & Indirect & Promotes migration and invasion via Wnt/ $\beta$-catenin signaling pathway. & (89) \\
\hline Ovarian Cancer & $\begin{array}{l}\operatorname{miR} \text { let-7d- } \\
5 p\end{array}$ & Downregulated & $2 / 9$ & Indirect & Promotes proliferation by regulating p53 signaling pathway via HMGA1. & (90) \\
\hline Ovarian Cancer & $\begin{array}{l}\mathrm{miR}- \\
1273 g-3 p\end{array}$ & Downregulated & $2 / 9$ & Indirect & Regulation of TNF- $\alpha$ and COL1A1. & (91) \\
\hline \multirow[t]{2}{*}{ Ovarian Cancer } & $\begin{array}{l}\operatorname{miR}-199 a- \\
5 p\end{array}$ & Downregulated & $2 / 9$ & Indirect & Promotes cellular growth, proliferation and invasion via NF-кB pathway. & $(92,93)$ \\
\hline & miR-9 & Downregulated & & Indirect & & \\
\hline Ovarian Cancer & $\mathrm{miR}-122$ & Downregulated & 2/14 & Indirect & Promotes EMT by targeting P4HA1. & (94) \\
\hline \multirow[t]{2}{*}{ Ovarian Cancer } & $\begin{array}{l}\operatorname{miR}-130 b- \\
3 p\end{array}$ & Downregulated & $2 / 9$ & Indirect & Promotes EMT, cellular attachment and proliferation & $(50,95)$ \\
\hline & miR-200 & Downregulated & & Indirect & through TGF- $\beta$ signaling pathway. & \\
\hline Ovarian Cancer & $\mathrm{miR}-17$ & Downregulated & 2 & Indirect & Promotes metastasis by regulating integrin $\alpha 5$ and $\beta 1$. & (96) \\
\hline Ovarian Cancer & $\mathrm{miR}-340$ & Downregulated & $2 / 9$ & Indirect & Promotes metastasis and inhibits apoptosis via NF-x03BA;B1 activation. & (97) \\
\hline Ovarian Cancer & $\operatorname{miR}-543$ & Downregulated & 7 & Direct & Promotes invasion by direct binding of miR-543 to 3'-UTR of MMP-7. & (98) \\
\hline
\end{tabular}

revealed CPEB1 and MMP-9 as the direct target of miR-183, also a binding region for 3'UTR of MMP-9 is found at the seed region of miR-183 $(75,76)$.

Von Hippel Lindau (VHL), a tumor suppressor, targets HIF $1 \alpha / 2 \alpha$ by ubiquitination involving E3 ligase to proteasomal degradation. Loss of VHL results in the accumulation of HIF1 $\alpha$ inside the nuclei and expression of HIF target genes which subsequently leads to oncogenesis (100). In OC, miR-92 inhibits VHL, which in turn de-repress HIF-1 $\alpha$. HIF- $1 \alpha$, in turn, stimulates VEGF by acting as a transcription factor together with p300 and p-STAT3 (99). Similarly, miR-210 is another important miRNA activated during the hypoxic condition and has a role in DNA damage response, mitochondrial metabolism, cellular proliferation, angiogenesis, and apoptotic cell death. Loss of VHL in OC stabilizes HIF-1 $\alpha$ which in turn stimulates miR-210 expression inducing tumor aggressiveness (79).

DNA methylation/histone acetylation forms a complex framework for epigenetic regulation during cancer development. An altered methylation pattern is seen in cancer cells, both globally and CpG islands in the promoter region (101), leading to aberrant gene activity during tumorigenesis. In EC, different levels of miR-130b expression and its $\mathrm{CpG}$ methylation were linked to MMP-2/9 expression and EMT- 
related genes. Reversing miR-130b promoter hypermethylation decreased EC cell malignancy, suggesting that CpG island hypermethylation-mediated miRNA silencing contributes to carcinogenesis and is related to aggressive tumor behavior via increased MMP-2/9 expression, however, the mechanism behind the regulation of MMP expression by this miRNA is still unknown (77).

\section{Tumor Suppressor miRNAs}

Tumor suppressor miRNAs are under-expressed during cancer progression and regulate cancer development by downregulating genes involved in tumorigenesis. The majority of ECs are accompanied by abnormal hormone signaling, where estrogen receptor $\alpha(\mathrm{ER} \alpha)$ behaves as oncogenic stimuli (102). Estrogen induction regulates cellular proliferation and subsequent invasion in EC and is accompanied by a downregulation of miR-22 in ER- $\alpha$ positive cell lines. Transfected miR-22 mimics into endometrial cells reduced the release of MMP-9 and MMP-2 thereby reversing $17 \beta$-estradiol (E2)-mediated progression of the cell cycle, cellular proliferation, and invasiveness of ER $\alpha$-positive EC cells (84).

miR-200 family members have an enormous function in multiple cancer types (103-106). miR-200b plays a key role in regulating EMT and is correlated with cancer growth, proliferation, drug resistance in numerous diseases $(107,108)$. Cytoskeletal remodeling is the central event in the metastatic spread of cancerous cells. Actin structures facilitate cell migration and invasion, disruption of which leads to increased metastatic spread (109). In CC, miR-200b can suppress RhoE function, which regulates actin cytoskeleton and cell migration by altering cell motility by targeting MMP-9 thus suppressing EMT (70). Another report showed that downregulation of miR200 family expression by TGF $\beta$ induced MMP-2, -9, and fibronectin 1 production and stimulated cancer cell attachment to human primary mesothelial cells (110). Catalpol induces miR200 expression which sequentially inhibits MMP-2 expression levels, decreases cell proliferation, and accelerates apoptosis in OC cells (50). Similarly, TGF $\beta 1$ induced EMT was linked with decreased miR-320a and increased MMP-3 and -9 expressions in EC cells. Excessive expression of miR-320a or miR-340-5p substantially inhibited HEC-1A (endometrial adenocarcinoma cell line) cell invasion and migration through its binding to eIF4E mRNA 3'-UTR and diminished TGF-1-induced EMT properties (85). Another report suggested the involvement of miR-130b-3p in EMT, invasion, migration in cancer various types, mainly via the TGF $\beta$ pathway $(111,112)$. In OC overexpression of CMPK, cytidine nucleoside monophosphate kinase is seen, and CMPK knockdown dramatically decreases the cellular proliferation, invasion, and migration, along with MMP-9/-2 expression in epithelial OC. Downregulation of miR-130b-3p is seen in EOC which upregulates CMPK via the TGF- $\beta$ signaling pathway (95).

Rak et al. showed a higher MMP-14 expression in endometrial adenocarcinoma tissue with a decrease in miR-410 level, suggesting a regulatory effect of miR-410 in modulating EC cell progression although the mechanism is largely unknown (13). Studies in odontoblast cells suggest the presence of a probable binding site for miR-410 on 3'UTR of MMP-14 (82). In lung cancer, miR-410 has a tumor-suppressive role by inducing apoptosis through downregulating JAK/STAT3/SOCS3 signaling pathway (113). Another miRNA, miR-195 has tumor-suppressive nature which negatively regulates cellular proliferation, migration, invasion, and promotes apoptosis (114-116). miR-195 overexpression ectopically decreased the viability, migration, and invasiveness of the endometrial carcinoma cell lines, along with the TIMP-2 upregulation and MMP-2/9 downregulation. miR195 targets GPER (G protein-coupled estrogen receptor) and reduced the phosphorylation levels of PI3K/AKT, thus negatively regulating EMT in endometrial carcinoma (83). miR195 also suppresses CC cellular proliferation, invasion, and migration through the TNF-pathway. The MMP-14 3'UTR binds to miR-195-5p directly through which its expression is directly inhibited. MMP-14 can modulate the expression of TNF$\alpha$. A downregulated miR-195-5p and an upregulated MMP-14 were noticed in CC (74).

miR-574-3p has an enormous role in cancer progression, EMT, metastasis, invasion, and chemosensitivity $(117,118)$. In epithelial OC, it inhibits the activation of AKT, FAK, c-Src, and MMP-9 by negatively regulating EGFR, inhibiting the cell invasion, and migration, and also increasing EOC cell sensitivity to paclitaxel and cisplatin (86). Different patterns of Let-7 family miRNAs were found in multiple cancers. In OC, let$7 \mathrm{~d}-5 \mathrm{p}$ induces cell apoptosis and rescues chemosensitivity to cisplatin by targeting HMGA1 directly and thereby regulating the p53 pathway, MMP-2 and -9, and apoptotic pathway (90).

miR-17 is a highly conserved 6-membered gene cluster and is shown to have numerous roles in various pathways (119-121). In OC cells, it is seen to be downregulated thereby suppressing its inhibitory action of peritoneal metastasis via targeting integrin $\alpha 5$ and $\beta 1$ and MMP-2 expression. miR-17 specifically binds to the $\alpha 5$ and $\beta 1$ integrins 3'UTR region directly and decreases their expression. The addition of miR-17 to OC cells in vitro showed a significant decrease in adhesion and invasion (96). miR-29b is dysregulated in various cancers. It has a tumor-suppressing role in $\mathrm{OC}$ and is seen to be involved in tumor malignancy. It increases the $\alpha$-SMA (mesenchymal cell markers) expression in fibroblasts which is a component of the cellular microenvironment that contributes to tumor malignancy by getting hyperactive and acquiring CAF (cancer-associated fibroblast) profile during carcinogenesis. These fibroblasts downregulate miR-29b expression in SKOV3 cells (ovarian cancer cell line), resulting in an increased invasion and migration. miR-29b can potentially target MMP-2 which is also found to be upregulated in OC (12). Studies in lung cancer metastasis also revealed the presence of a binding site of miR-29b at the MMP-2 3'UTR region through which it downregulates MMP-2 expression (87).miR-543 has been seen to be dysregulated in many cancers. It regulates proliferation, migration/invasion, EMT, metastasis, and many other pathways (122-124). miR-543 suppresses MMP-7 gene translation via the direct binding of MMP-7 3'-UTR whereas placental growth factor (PLGF), an angiogenic factor, represses the inhibitory action of miR-543 activating the MMP-7 mediated EMT and invasion in OC (98). Certain miRNAs have a dual role in carcinogenesis. 
Although previously stated that miR-183 is oncogenic, it is also seen to possess a tumor-suppressive function. In CC tissues, miR183 expression was notably reduced whereas MMP-9 expression was elevated. The addition of miR-183 in-vitro resulted in a reduced invasion and migration of $\mathrm{CC}$ cell lines, via directly targeting MMP-9 and reduction of metastatic capability. A presence of a possible binding site of miR-183 was found at the 3'UTR regions of the MMP-9 gene (71).

\section{PREDICTING THE ROLE OF MMPS IN CANCER SIGNALING PATHWAYS}

To have a better understanding of the functions of MMPs and their regulation in cancer, an interaction plot has been created in String database (http://www.string-db.org) and analyzed in Cytoscape ver 3.8.1. Initially, miRwalk and miRmap database were used to find the miRNA and understand the regulating MMPs in gynecological cancer. The MMPs and their correlated genes were selected with $\mathrm{k}$ mean value of 0.23 , neighborhood active interaction source, with a minimum confidence score of 0.45 and minimum stringency. As shown in Figure 2, MMP-9, $-3,-7$ and -2 are considered hub genes since most of the proteinprotein interactions are seen among them. MMP-9, $-7,-3,-2,-8$ and -14 also show proximity to each other, hence they are correlated in each other's biochemical activity. A significant positive correlation is also seen in MMPs interacting with genes viz; ADAM17, PLAUR, TGFB1, SERPINE1, STAT3, EGF and TIMP. Results showed a positive correlation with genes involved in tumorigenesis and extracellular matrix proteins (125-130). IGF1, VEGFA, STAT3, PLG, ACAN and TIMP-2 were found to directly regulate with MMP-3, MMP-9 and MMP-7, respectively (Figure 2).

Screening of the miRNA was performed from the miRNA library and enrichment analysis was performed to understand the cellular activity and biochemical pathways in the form of a heat map showing the association of miRNAs involved in signaling pathways was created in miRpath (https://tools4mirs. org/software/target_functional_analysis/mirtar/). Recent evidence suggests the participation of miRNA in regulating MMP gene expression and is associated with key physiological pathways like TGF $\beta$, Rap1, Toll-like, Hippo, B cell and T cell receptor signaling pathway (131-136) (Figure 3). miRNAs regulate the actin cytoskeleton, which works synergistically on MMP regulation during cancer growth and metastasis $(137,138)$. As seen from th heatmap, among the miRNAs reported to regulate MMPs in gynecological cancer, miR-199-5p, miR-21$5 p, \operatorname{miR}-145-5 p$ and miR-29b-3p have shown the highest

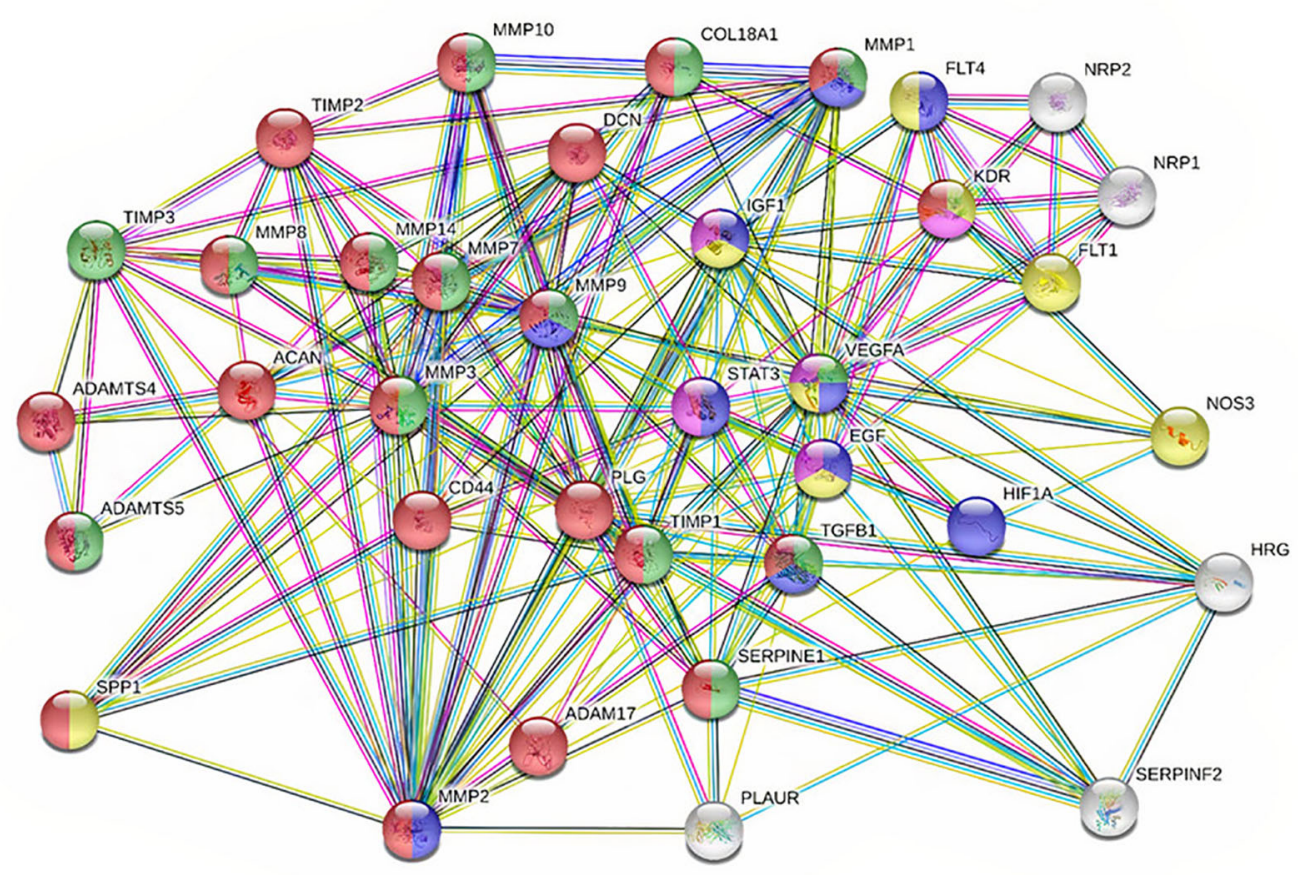

FIGURE 2 | PPI network showing 36 associated proteins in cancer. The nodes are each candidate. Edges represent their interactions. The divisions with nodes are the shared functions. Blue symbolizes those that have a function in cell proliferation. Green and Red are the ones regulating ECM. Yellow are those with proliferation and angiogenesis. 


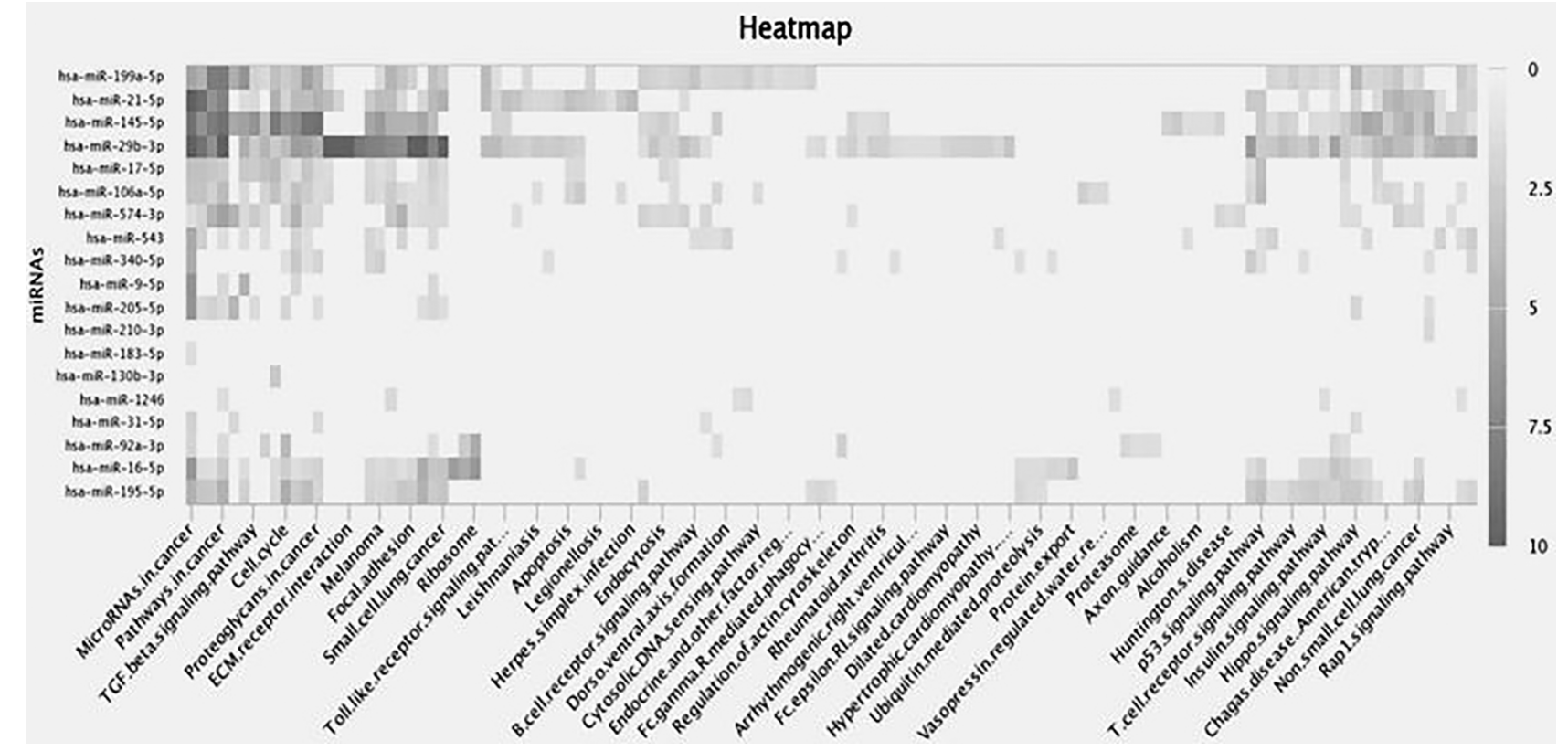

FIGURE 3 | Heat map depicts differential expression of miRNAs in various biological processes. Rows represent enrichment results for the target miRNAs whereas columns show biochemical pathways. Each highlighted miRNA is correlated to the adjacent biological process in the black color gradient. The color of individual fields represents P-value of the enrichment results. The dark shade shows a strong correlation between miRNA and the target pathways, the light shades correspond to weaker ones, whereas transparent area explains no role of miRNA in that process.

correlation with cancer-related signaling pathways (Figure 3). miR-145-5p and miR-21-5p are associated with TGF Band Hippo signaling pathway whereas miR-29b-3p regulates FAK pathway, Insulin pathway and p53 signaling pathway, along with ECM receptor interactions and is also shown to play a crucial role in small cell lung cancer and melanoma (Figure 3). From literature studies, we found that miR-29b directly binds to MMP -2 3'UTR and regulates their expression in OC (12). Prudent manipulation of these miRNAs can therefore regulate MMP production in cancer cells and can act as antitumor agents.

\section{miRNA-BASED ANTI-CANCER THERAPEUTIC STRATEGIES}

miRNA-based therapeutic protocols for regulating gene expression can be divided into two main strategies: miRNA anti-sense therapy and miRNA replacement therapy. Inhibition of oncomiRs synthesis can be achieved by using miRNA inhibitors or oligomers and, on the other hand, enhancement of miRNA activity can be achieved by replacement of oncomiRs with the viral vector-mediated introduction of tumor suppressor miRNAs in a cell-specific manner for reprogramming target cells. Strategies to inhibit oncomiRs biogenesis by small-molecule inhibitors, antagomiRs, miRNA sponges, miRNA masking and approaches for replacement of miRNAs, including lentiviral vectors, tumor-suppressor miRNA mimics, CRISPR/Cas-like genome editing tools, are currently being investigated as potential cancer therapeutics.
Locked nucleic acid (LNA), a class of high-affinity bicyclic RNA analogs, can detect miRNA in tissues and inhibit their function in vitro and in vivo studies. Miravirsen, a short locked nucleic acid complementary to miR-122 (Roche/Santaris) is the world's first miRNA drug candidate in phase II clinical trials for hepatitis C virus treatment, along with RG-101, an Nacetylgalactosamine-conjugated anti-miR targeting miR-122 (139, 140). Furthermore, tumor suppressor miRNA replacement has been explored utilizing miRNA mimics/ lentiviral vectors producing miRNA, which may influence endogenous miRNA expression (141-144). As an alternative to lentiviral vectors that show off-target effects, nonviral miRNA delivery techniques like polyethyleneimine (PEI)-based nanoparticles, liposomes, polymeric micelles, and dendrimers have been proposed. MRX34 was the first miRNA replacement therapy in modified liposomes to enter clinical trials, restoring a tumor suppressor miRNA, miR-34, with promising outcomes in stage I trials (139).

Several potential small molecule drugs targeting enzymes involved in miRNA biogenesis have been identified using comprehensive compound library screening. miR-21 is upregulated in most cancers and suppression of PTEN by miR-21 can contribute to chemoresistance via activating the Akt/ERK pathways (145). Screening for small molecules modulating miR-21 activity resulted in the discovery of a novel etheramide backbone which led to a reduction in CC cell proliferation and tumor growth, as well as the activation of apoptosis by activating caspase-3/7 (145). 


\section{Cancerous Cells}

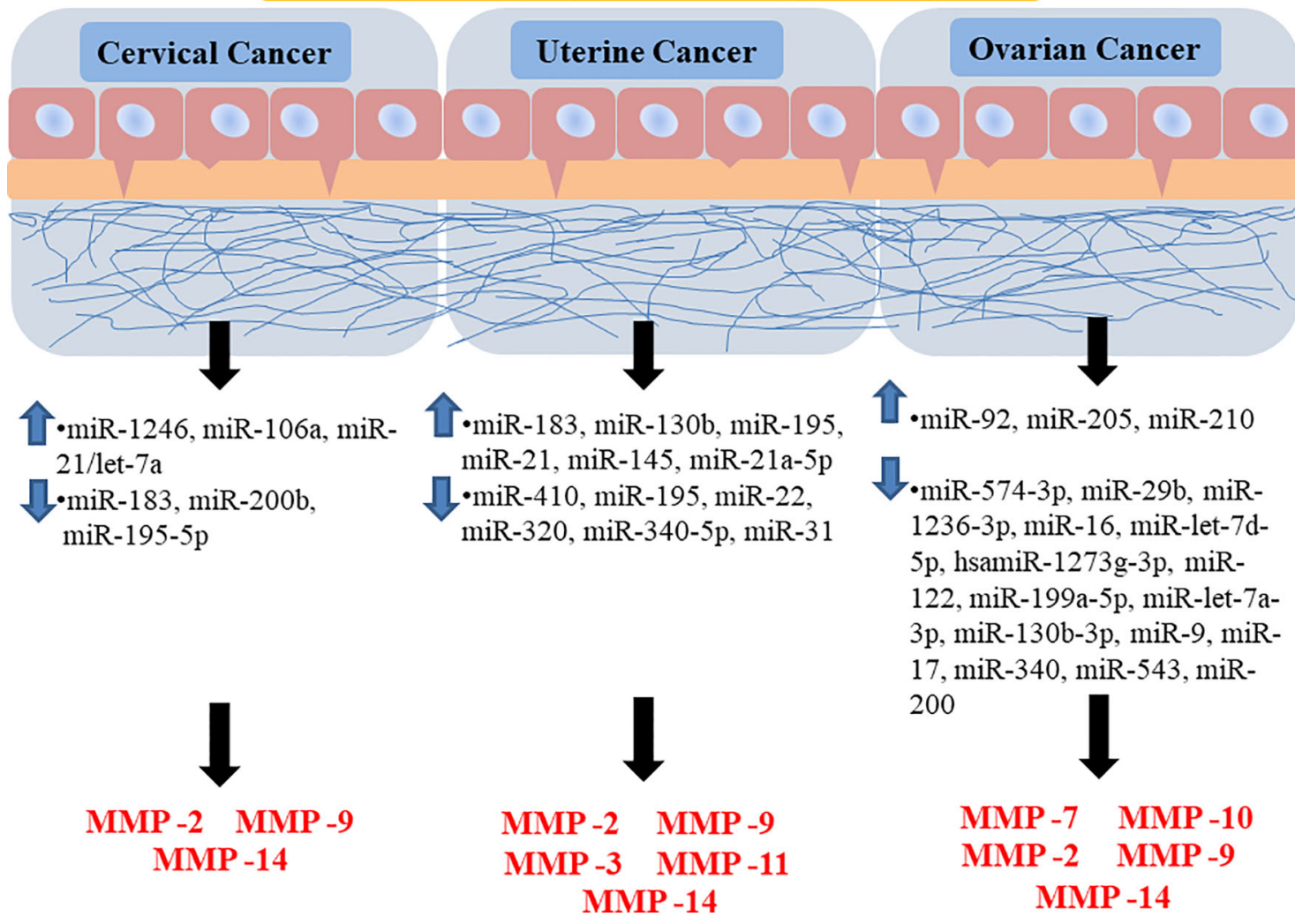

FIGURE 4 | Diagrammatic representation showing the regulation of different MMPs through different miRNAs in various forms of gynecological cancer. It is showing how the upregulation or downregulation of certain miRNAs is promoting the expression of certain MMPs in a specific type of gynecological cancer. Highlighted miRNAs are highly correlated to major signaling pathways and target MMP-9/2 activities. MMP, Matrix Metalloprotease; miR, MicroRNA.

miRNA sponges are artificial transcripts containing several complementary binding sites for one or more miRNA of interest and can block the activity of multiple miRNAs sharing the same seed sequence. miR-9 reduced the expression of KLF17, CDH1, and LASS2 (tumor suppressor genes). A DNA sponge with four miR-9 binding sites was demonstrated to effectively inhibit miR9 activity, restoring natural expression of KLF17, CDH1, and LASS2 (146). Researchers are also focusing on utilizing CRISPR/ Cas9 gene-editing system for miRNAs inhibition. In human colon cancer cell lines targeting of miR-17/miR-200c/miR-141 loci was done using CRISPR/Cas9 resulting in decreased levels of mature miRNA and low off-target effects (147).

Combination strategies based on the co-administration of miRNA targeting agents along with antitumor drugs have been observed to eradicate drug-resistant tumor cells to treatment and have greater anticancer effects. Nano-liposome-based delivery of miR-205 mimic was shown to sensitize the tumor to radiation therapy in breast cancer xenograft model (148). In another example, PDL1 expression in tumor cells was decreased when mir-34a mimics (MRX34) were combined with radiation (149). Therefore, combining miRNA replacement therapies with conventional anticancer drugs reveal excellent results and presents a novel possibility of chemotherapeutic treatment regimens.

The capacity to target several genes in a particular pathway and efficiently build novel therapeutic components are two advantages of miRNA-based treatment. Given that a single miRNA may regulate multiple MMPs and their downstream signaling pathways amplifies the scope of utilizing miRNAs to act as an attractive candidate for anticancer treatments. However, this also invites additional problems of non-specific target inhibition by miRNAs. Targeting MMPs has been clinically challenging due to the non-specificity and musculoskeletal toxicity of the inhibitors (150). Therefore, precision medicine designed to target the MMPs increased in a particular tumor in a patient might show a potential resolution for this issue.

Even though there are no FDA-approved miRNA therapy candidates for medical intervention to date, potential candidate drugs are in clinical development or are in phase I and II clinical studies (151). Nanoparticle-based, tissue-specific miRNA-drug delivery to a particular lesion in a patient, can improve solubility and efficacy of the medicine while avoiding contact with healthy tissues. Intratumoral injections of miRNA-based therapeutics 
directly into the pathogenic site can improve bioavailability, target specificity, effectiveness, and reduce adverse effects in cancer-related diseases $(152,153)$. Computational deeplearning-based approaches for accurately predicting human miRNA targets at the site level in patients have enabled the use of huge multi-omics data and increased the robustness of prediction models. It is critical to design a good delivery mechanism with high specificity for targeting cells to execute miRNA replacement therapy. As a result, miRNA replacement therapy may be a unique and appealing treatment option for a variety of cancers, and it is vital to research how to carry the appropriate miRNA based on the kind of cancer.

\section{CONCLUSION AND FUTURE PROSPECTS}

MMPs are powerful regulators of cellular proliferation, differentiation, angiogenesis, migration, and apoptosis. MMPs are appealing targets for the creation of selective inhibitors with high therapeutic potential. However, all of the clinical trials in advanced cancer patients with MMP inhibitors were unsuccessful. Numerous MMP inhibitors, including small molecules and blocking antibodies, have been produced as drug candidates to attenuate MMP production but most of their effects tend to be majorly nonspecific. Since MMPs contain similar active sites and play multiple crucial roles in important biological processes, making it is challenging to construct highly selective MMP inhibitors with low toxicities. Therefore, to increase the clinical utility of MMPs for tumor therapy, new MMP inhibitors should be able to individually regulate individual MMPs as well as manage a network of interlinked molecules. The ability of miRNAs to regulate potentially hundreds of genes in a cell-specific manner makes it a powerful target for anticancer treatment (Figure 4). Since miRNAs may target MMPs more selectively without interfering with the structural similarities of MMP catalytic domains, miRNA-mediated MMP regulation may lead to the creation of

\section{REFERENCES}

1. Bray F, Ferlay J, Soerjomataram I, Siegel RL, Torre LA, Jemal A. Global Cancer Statistics 2018: GLOBOCAN Estimates of Incidence and Mortality Worldwide for 36 Cancers in 185 Countries. CA Cancer J Clin (2018) 68 (6):394-424. doi: 10.3322/caac. 21492

2. Dumas L, Ring A, Butler J, Kalsi T, Harari D, Banerjee S. Improving Outcomes for Older Women With Gynaecological Malignancies. Cancer Treat Rev (2016) 50:99-108. doi: 10.1016/j.ctrv.2016.08.007

3. Ottevanger PB. Ovarian Cancer Stem Cells More Questions Than Answers. Semin Cancer Biol (2017) 44:67-71. doi: 10.1016/j.semcancer.2017.04.009

4. Medhin LB, Tekle LA, Achila OO, Said S. Incidence of Cervical, Ovarian and Uterine Cancer in Eritrea: Data From the National Health Laboratory, 20112017. Sci Rep (2020) 10(1):9099. doi: 10.1038/s41598-020-66096-5

5. Visse R, Nagase H. Matrix Metalloproteinases and Tissue Inhibitors of Metalloproteinases: Structure, Function, and Biochemistry. Circ Res (2003) 92(8):827-39. doi: 10.1161/01.RES.0000070112.80711.3D

6. Vizoso FJ, Gonzalez LO, Corte MD, Rodriguez JC, Vazquez J, Lamelas ML, et al. Study of Matrix Metalloproteinases and Their Inhibitors in Breast Cancer. Br J Cancer (2007) 96(6):903-11. doi: 10.1038/sj.bjc.6603666
MMP inhibitors. Furthermore, miRNAs may target several molecules, often in the context of a network, making them particularly effective at controlling various biological processes essential to malignant tumors. Comprehensive inter-atomic analyses of miRNAs involved in regulating signaling pathways associated with cancer development and progression might aid in establishing druggable targets for antitumor treatment. Therefore, targeting such miRNA will not only help in understanding their functions but also the underlying cause of several gynecological disorders arising today. For probing miRNA-MMP as an anticancer treatment, proper validation and optimization of miRNA functional role are required in the clinical system, xenograft and orthotopic models to elucidate a detailed understanding of their efficacy in carcinogenesis and for their journey from bench to clinic. Pharmaceutical companies are constantly developing new miRNA-MMP therapies of low cytotoxicity and limited side effects. Whether new technologies targeting miRNAs that regulate MMPs can successfully be employed to delay or stop cancer progression remains to be seen.

\section{AUTHOR CONTRIBUTIONS}

Authors AP and YB were responsible for constructing the title, performing literature study, writing, illustration, and table preparation. SS and AS had taken the initiative of the work and gave their feedback on the study. PS carried out in silico studies and critically reviewed the article. All authors contributed to manuscript revision, read, and approved the submitted version.

\section{FUNDING}

$\mathrm{AP}$ and $\mathrm{YB}$ are recipients of CSIR and UGC Fellowship, Government of India, respectively. PS gratefully acknowledges the financial support of DBT-RA Program in Biotechnology and Life Sciences, Government of India.

7. Hsu CP, Shen GH, Ko JL. Matrix Metalloproteinase-13 Expression Is Associated With Bone Marrow Microinvolvement and Prognosis in NonSmall Cell Lung Cancer. Lung Cancer (2006) 52(3):349-57. doi: 10.1016/ j.lungcan.2006.01.011

8. Peng WJ, Zhang JQ, Wang BX, Pan HF, Lu MM, Wang J. Prognostic Value of Matrix Metalloproteinase 9 Expression in Patients With non-Small Cell Lung Cancer. Clin Chim Acta (2012) 413(13-14):1121-6. doi: 10.1016/ j.cca.2012.03.012

9. Zhang Q, Liu S, Parajuli KR, Zhang W, Zhang K, Mo Z, et al. Interleukin-17 Promotes Prostate Cancer via MMP7-Induced Epithelial-to-Mesenchymal Transition. Oncogene (2017) 36(5):687-99. doi: 10.1038/onc.2016.240

10. Kotepui M, Thawornkuno C, Chavalitshewinkoon-Petmitr P, Punyarit P, Petmitr S. Quantitative Real-Time RT-PCR of ITGA7, SVEP1, TNS1, LPHN3, SEMA3G, KLB and MMP13 mRNA Expression in Breast Cancer. Asian Pac J Cancer Prev (2012) 13(11):5879-82. doi: 10.7314/APJCP.2012.13.11.5879

11. Li L, Li H. Role of microRNA-Mediated MMP Regulation in the Treatment and Diagnosis of Malignant Tumors. Cancer Biol Ther (2013) 14(9):796805. doi: $10.4161 /$ cbt.25936

12. Medeiros M, Ribeiro AO, Lupi LA, Romualdo GR, Pinhal D, Chuffa LGA, et al. Mimicking the Tumor Microenvironment: Fibroblasts Reduce 
miR-29b Expression and Increase the Motility of Ovarian Cancer Cells in a Co-Culture Model. Biochem Biophys Res Commun (2019) 516(1):96-101. doi: 10.1016/j.bbrc.2019.06.001

13. Rak B, Garbicz F, Paskal W, Pelka K, Marczewska JM, Wolosz D, et al. The Expression of MMP-14 and microRNA-410 in FFPE Tissues of Human Endometrial Adenocarcinoma. Histol Histopathol (2016) 31(8):911-20. doi: 10.14670/HH-11-728

14. Sun XY, Han XM, Zhao XL, Cheng XM, Zhang Y. MiR-93-5p Promotes Cervical Cancer Progression by Targeting THBS2/MMPS Signal Pathway. Eur Rev Med Pharmacol Sci (2019) 23(12):5113-21. doi: 10.26355/ eurrev_201906_18175

15. Ghildiyal M, Zamore PD. Small Silencing RNAs: An Expanding Universe. Nat Rev Genet (2009) 10(2):94-108. doi: 10.1038/nrg2504

16. Ha M, Kim VN. Regulation of microRNA Biogenesis. Nat Rev Mol Cell Biol (2014) 15(8):509-24. doi: 10.1038/nrm3838

17. Bartel DP. MicroRNAs: Target Recognition and Regulatory Functions. Cell (2009) 136(2):215-33. doi: 10.1016/j.cell.2009.01.002

18. Huntzinger E, Izaurralde E. Gene Silencing by microRNAs: Contributions of Translational Repression and mRNA Decay. Nat Rev Genet (2011) 12(2):99110. doi: $10.1038 / \mathrm{nrg} 2936$

19. Lin S, Gregory RI. MicroRNA Biogenesis Pathways in Cancer. Nat Rev Cancer (2015) 15(6):321-33. doi: 10.1038/nrc3932

20. He L, Thomson JM, Hemann MT, Hernando-Monge E, Mu D, Goodson S, et al. A microRNA Polycistron as a Potential Human Oncogene. Nature (2005) 435(7043):828-33. doi: 10.1038/nature03552

21. Kim HH, Kuwano Y, Srikantan S, Lee EK, Martindale JL, Gorospe M. HuR Recruits Let-7/RISC to Repress C-Myc Expression. Genes Dev (2009) 23 (15):1743-8. doi: 10.1101/gad.1812509

22. Johnson SM, Grosshans H, Shingara J, Byrom M, Jarvis R, Cheng A, et al. RAS Is Regulated by the Let-7 microRNA Family. Cell (2005) 120(5):635-47. doi: 10.1016/j.cell.2005.01.014

23. Kumar MS, Erkeland SJ, Pester RE, Chen CY, Ebert MS, Sharp PA, et al. Suppression of Non-Small Cell Lung Tumor Development by the Let-7 microRNA Family. Proc Natl Acad Sci USA (2008) 105(10):3903-8. doi: 10.1073/pnas.0712321105

24. Lu J, Getz G, Miska EA, Alvarez-Saavedra E, Lamb J, Peck D, et al. MicroRNA Expression Profiles Classify Human Cancers. Nature (2005) 435(7043):834-8. doi: 10.1038/nature03702

25. Thomson JM, Newman M, Parker JS, Morin-Kensicki EM, Wright T, Hammond SM. Extensive Post-Transcriptional Regulation of microRNAs and its Implications for Cancer. Genes Dev (2006) 20(16):2202-7. doi: 10.1101/gad.1444406

26. Michlewski G, Caceres JF. Post-Transcriptional Control of miRNA Biogenesis. RNA (2019) 25(1):1-16. doi: 10.1261/rna.068692.118

27. Hutvagner G, McLachlan J, Pasquinelli AE, Balint E, Tuschl T, Zamore PD. A Cellular Function for the RNA-Interference Enzyme Dicer in the Maturation of the Let-7 Small Temporal RNA. Science (2001) 293 (5531):834-8. doi: 10.1126/science.1062961

28. Lund E, Guttinger S, Calado A, Dahlberg JE, Kutay U. Nuclear Export of microRNA Precursors. Science (2004) 303(5654):95-8. doi: 10.1126/ science.1090599

29. The Knowledge of Pharmacological Therapy of a Group of Calabrian Nurses. The Cultural Association of Nurses of Catanzaro and the Ospedale Di Matera Working Group. Riv Inferm (1992) 11(2):71-80.

30. Rorbach G, Unold O, Konopka BM. Distinguishing Mirtrons From Canonical miRNAs With Data Exploration and Machine Learning Methods. Sci Rep (2018) 8(1):7560. doi: 10.1038/s41598-018-25578-3

31. Tocchi A, Parks WC. Functional Interactions Between Matrix Metalloproteinases and Glycosaminoglycans. FEBS J (2013) 280(10):233241. doi: $10.1111 /$ febs. 12198

32. Mehana EE, Khafaga AF, El-Blehi SS. The Role of Matrix Metalloproteinases in Osteoarthritis Pathogenesis: An Updated Review. Life Sci (2019) 234:116786. doi: 10.1016/j.lfs.2019.116786

33. Scheau C, Badarau IA, Costache R, Caruntu C, Mihai GL, Didilescu AC, et al. The Role of Matrix Metalloproteinases in the Epithelial-Mesenchymal Transition of Hepatocellular Carcinoma. Anal Cell Pathol (Amst) (2019) 2019:9423907. doi: 10.1155/2019/9423907
34. Cui N, Hu M, Khalil RA. Biochemical and Biological Attributes of Matrix Metalloproteinases. Prog Mol Biol Transl Sci (2017) 147:1-73. doi: 10.1016/ bs.pmbts.2017.02.005

35. Baker AH, Edwards DR, Murphy G. Metalloproteinase Inhibitors: Biological Actions and Therapeutic Opportunities. J Cell Sci (2002) 115(Pt 19):371927. doi: 10.1242 /jcs. 00063

36. Mannello F, Tonti G, Papa S. Matrix Metalloproteinase Inhibitors as Anticancer Therapeutics. Curr Cancer Drug Targets (2005) 5(4):285-98. doi: $10.2174 / 1568009054064615$

37. Chambers AF, Matrisian LM. Changing Views of the Role of Matrix Metalloproteinases in Metastasis. J Natl Cancer Inst (1997) 89(17):126070. doi: $10.1093 /$ jnci/89.17.1260

38. Dong H, Diao H, Zhao Y, Xu H, Pei S, Gao J, et al. Overexpression of Matrix Metalloproteinase-9 in Breast Cancer Cell Lines Remarkably Increases the Cell Malignancy Largely via Activation of Transforming Growth Factor Beta/SMAD Signalling. Cell Prolif (2019) 52(5):e12633. doi: 10.1111/ cpr. 12633

39. Bredin CG, Liu Z, Klominek J. Growth Factor-Enhanced Expression and Activity of Matrix Metalloproteases in Human Non-Small Cell Lung Cancer Cell Lines. Anticancer Res (2003) 23(6C):4877-84.

40. Massague J. TGFbeta in Cancer. Cell (2008) 134(2):215-30. doi: 10.1016/ j.cell.2008.07.001

41. Dallas SL, Rosser JL, Mundy GR, Bonewald LF. Proteolysis of Latent Transforming Growth Factor-Beta (TGF-Beta)-Binding Protein-1 by Osteoclasts. A Cellular Mechanism for Release of TGF-Beta From Bone Matrix. J Biol Chem (2002) 277(24):21352-60. doi: 10.1074/jbc.M111663200

42. Behrens $\mathrm{P}$, Rothe M, Florin A, Wellmann A, Wernert N. Invasive Properties of Serous Human Epithelial Ovarian Tumors Are Related to Ets-1, MMP-1 and MMP-9 Expression. Int J Mol Med (2001) 8(2):149-54. doi: 10.3892/ ijmm.8.2.149

43. Tian R, Li X, Gao Y, Li Y, Yang P, Wang K. Identification and Validation of the Role of Matrix Metalloproteinase-1 in Cervical Cancer. Int J Oncol (2018) 52(4):1198-208. doi: 10.3892/ijo.2018.4267

44. Zhu L, Zheng X, Du Y, Xing Y, Xu K, Cui L. Matrix Metalloproteinase-7 may Serve as a Novel Biomarker for Cervical Cancer. Onco Targets Ther (2018) 11:4207-20. doi: 10.2147/OTT.S160998

45. Wang CH, Li YH, Tian HL, Bao XX, Wang ZM. Long non-Coding RNA BLACAT1 Promotes Cell Proliferation, Migration and Invasion in Cervical Cancer Through Activation of Wnt/Beta-Catenin Signaling Pathway. Eur Rev Med Pharmacol Sci (2018) 22(10):3002-9. doi: 10.26355/ eurrev_201805_15057

46. Al-Alem LF, McCord LA, Southard RC, Kilgore MW, Curry TE Jr. Activation of the PKC Pathway Stimulates Ovarian Cancer Cell Proliferation, Migration, and Expression of MMP7 and MMP10. Biol Reprod (2013) 89(3):73. doi: 10.1095/biolreprod.112.102327

47. Wang F, Chang Z, Fan Q, Wang L. Epigallocatechin3gallate Inhibits the Proliferation and Migration of Human Ovarian Carcinoma Cells by Modulating P38 Kinase and Matrix Metalloproteinase2. Mol Med Rep (2014) 9(3):1085-9. doi: 10.3892/mmr.2014.1909

48. Meyer E, Vollmer JY, Bovey R, Stamenkovic I. Matrix Metalloproteinases 9 and 10 Inhibit Protein Kinase C-Potentiated, P53-Mediated Apoptosis. Cancer Res (2005) 65(10):4261-72. doi: 10.1158/0008-5472.CAN-04-2908

49. Pu Z, Zhu M, Kong F. Telmisartan Prevents Proliferation and Promotes Apoptosis of Human Ovarian Cancer Cells Through Upregulating PPARgamma and Downregulating MMP9 Expression. Mol Med Rep (2016) 13(1):555-9. doi: 10.3892/mmr.2015.4512

50. Gao N, Tian JX, Shang YH, Zhao DY, Wu T. Catalpol Suppresses Proliferation and Facilitates Apoptosis of OVCAR-3 Ovarian Cancer Cells Through Upregulating microRNA-200 and Downregulating MMP-2 Expression. Int J Mol Sci (2014) 15(11):19394-405. doi: 10.3390/ ijms151119394

51. Khasigov PZ, Podobed OV, Gracheva TS, Salbiev KD, Grachev SV, Berezov TT. Role of Matrix Metalloproteinases and Their Inhibitors in Tumor Invasion and Metastasis. Biochem (Mosc) (2003) 68(7):711-7. doi: 10.1023/A:1025051214001

52. Davidson B, Goldberg I, Gotlieb WH, Kopolovic J, Ben-Baruch G, Nesland JM, et al. High Levels of MMP-2, MMP-9, MT1-MMP and TIMP-2 mRNA 
Correlate With Poor Survival in Ovarian Carcinoma. Clin Exp Metastasis (1999) 17(10):799-808. doi: 10.1023/A:1006723011835

53. Cortez-Retamozo V, Etzrodt M, Newton A, Rauch PJ, Chudnovskiy A, Berger C, et al. Origins of Tumor-Associated Macrophages and Neutrophils. Proc Natl Acad Sci (2012) 109(7):2491-6. doi: 10.1073/pnas.1113744109

54. Kenny HA, Lengyel E. MMP-2 Functions as an Early Response Protein in Ovarian Cancer Metastasis. Cell Cycle (2009) 8(5):683-8. doi: 10.4161/ cc.8.5.7703

55. Mitra A, Chakrabarti J, Chattopadhyay N, Chatterjee A. MembraneAssociated MMP-2 in Human Cervical Cancer. J Environ Pathol Toxicol Oncol (2003) 22(2):93-100. doi: 10.1615/jenvpathtoxoncol.v22.i2.20

56. Piura B, Rabinovich A, Huleihel M. Matrix Metalloproteinases and Their Tissue Inhibitors in Malignancies of the Female Genital Tract. Harefuah (2003) 142(11):786-91, 804

57. Brun JL, Cortez A, Commo F, Uzan S, Rouzier R, Darai E. Serous and Mucinous Ovarian Tumors Express Different Profiles of MMP-2, -7, -9, MT1-MMP, and TIMP-1 and -2. Int J Oncol (2008) 33(6):1239-46.

58. Li Y, Jin X, Kang S, Wang Y, Du H, Zhang J, et al. Polymorphisms in the Promoter Regions of the Matrix Metalloproteinases-1, -3, -7, and -9 and the Risk of Epithelial Ovarian Cancer in China. Gynecol Oncol (2006) 101(1):926. doi: 10.1016/j.ygyno.2005.09.058

59. Guo H, Dai Y, Wang A, Wang C, Sun L, Wang Z. Association Between Expression of MMP-7 and MMP-9 and Pelvic Lymph Node and Para-Aortic Lymph Node Metastasis in Early Cervical Cancer. J Obstet Gynaecol Res (2018) 44(7):1274-83. doi: 10.1111/jog.13659

60. Su Y, Gao L, Teng L, Wang Y, Cui J, Peng S, et al. Id1 Enhances Human Ovarian Cancer Endothelial Progenitor Cell Angiogenesis via PI3K/Akt and NF-Kappab/MMP-2 Signaling Pathways. J Transl Med (2013) 11:132. doi: 10.1186/1479-5876-11-132

61. Wang FQ, Fisher J, Fishman DA. MMP-1-PAR1 Axis Mediates LPAInduced Epithelial Ovarian Cancer (EOC) Invasion. Gynecol Oncol (2011) 120(2):247-55. doi: 10.1016/j.ygyno.2010.10.032

62. Agarwal A, Tressel SL, Kaimal R, Balla M, Lam FH, Covic L, et al. Identification of a Metalloprotease-Chemokine Signaling System in the Ovarian Cancer Microenvironment: Implications for Antiangiogenic Therapy. Cancer Res (2010) 70(14):5880-90. doi: 10.1158/0008-5472.CAN-09-4341

63. Belotti D, Paganoni P, Manenti L, Garofalo A, Marchini S, Taraboletti G, et al. Matrix Metalloproteinases (MMP9 and MMP2) Induce the Release of Vascular Endothelial Growth Factor (VEGF) by Ovarian Carcinoma Cells: Implications for Ascites Formation. Cancer Res (2003) 63(17):5224-9.

64. Huang S, Van Arsdall M, Tedjarati S, McCarty M, Wu W, Langley R, et al. Contributions of Stromal Metalloproteinase-9 to Angiogenesis and Growth of Human Ovarian Carcinoma in Mice. J Natl Cancer Inst (2002) 94 (15):1134-42. doi: 10.1093/jnci/94.15.1134

65. Duellman T, Warren C, Yang J. Single Nucleotide Polymorphism-Specific Regulation of Matrix Metalloproteinase- 9 by Multiple miRNAs Targeting the Coding Exon. Nucleic Acids Res (2014) 42(9):5518-31. doi: 10.1093/nar/ gku197

66. Wang X, Chen X, Sun L, Bi X, He H, Chen L, et al. MicroRNA34a Inhibits Cell Growth and Migration in Human Glioma Cells via MMP9. Mol Med Rep (2019) 20(1):57-64. doi: 10.3892/mmr.2019.10233

67. Karimi L, Zeinali T, Hosseinahli N, Mansoori B, Mohammadi A, Yousefi M, et al. miRNA-143 Replacement Therapy Harnesses the Proliferation and Migration of Colorectal Cancer Cells In Vitro. J Cell Physiol (2019) 234 (11):21359-68. doi: 10.1002/jcp.28745

68. Li Q, Zhao H, Chen W, Huang P, Bi J. Human Keratinocyte-Derived Microvesicle miRNA-21 Promotes Skin Wound Healing in Diabetic Rats Through Facilitating Fibroblast Function and Angiogenesis. Int J Biochem Cell Biol (2019) 114:105570. doi: 10.1016/j.biocel.2019.105570

69. Li X, Zhou Q, Tao L, Yu C. MicroRNA-106a Promotes Cell Migration and Invasion by Targeting Tissue Inhibitor of Matrix Metalloproteinase 2 in Cervical Cancer. Oncol Rep (2017) 38(3):1774-82. doi: 10.3892/or.2017.5832

70. Cheng YX, Chen GT, Chen C, Zhang QF, Pan F, Hu M, et al. MicroRNA200b Inhibits Epithelial-Mesenchymal Transition and Migration of Cervical Cancer Cells by Directly Targeting RhoE. Mol Med Rep (2016) 13(4):313946. doi: $10.3892 / \mathrm{mmr} .2016 .4933$

71. Fan D, Wang Y, Qi P, Chen Y, Xu P, Yang X, et al. MicroRNA-183 Functions as the Tumor Suppressor via Inhibiting Cellular Invasion and Metastasis by
Targeting MMP-9 in Cervical Cancer. Gynecol Oncol (2016) 141(1):166-74. doi: 10.1016/j.ygyno.2016.02.006

72. Chen J, Yao D, Zhao S, He C, Ding N, Li L, et al. MiR-1246 Promotes SiHa Cervical Cancer Cell Proliferation, Invasion, and Migration Through Suppression of its Target Gene Thrombospondin 2. Arch Gynecol Obstet (2014) 290(4):725-32. doi: 10.1007/s00404-014-3260-2

73. Shishodia G, Shukla S, Srivastava Y, Masaldan S, Mehta S, Bhambhani S, et al. Alterations in microRNAs miR-21 and Let-7a Correlate With Aberrant STAT3 Signaling and Downstream Effects During Cervical Carcinogenesis. Mol Cancer (2015) 14:116. doi: 10.1186/s12943-015-0385-2

74. Li M, Ren CX, Zhang JM, Xin XY, Hua T, Wang HB, et al. The Effects of miR-195-5p/MMP14 on Proliferation and Invasion of Cervical Carcinoma Cells Through TNF Signaling Pathway Based on Bioinformatics Analysis of Microarray Profiling. Cell Physiol Biochem (2018) 50(4):1398-413. doi: $10.1159 / 000494602$

75. Xiong H, Chen R, Liu S, Lin Q, Chen H, Jiang Q. MicroRNA-183 Induces Epithelial-Mesenchymal Transition and Promotes Endometrial Cancer Cell Migration and Invasion in by Targeting CPEB1. J Cell Biochem (2018) 119 (10):8123-37. doi: $10.1002 /$ jcb.26763

76. Ruan H, Liang X, Zhao W, Ma L, Zhao Y. The Effects of microRNA-183 Promots Cell Proliferation and Invasion by Targeting MMP-9 in Endometrial Cancer. BioMed Pharmacother (2017) 89:812-8. doi: 10.1016/ j.biopha.2017.02.091

77. Li BL, Lu W, Lu C, Qu JJ, Yang TT, Yan Q, et al. CpG Island Hypermethylation-Associated Silencing of microRNAs Promotes Human Endometrial Cancer. Cancer Cell Int (2013) 13(1):44. doi: 10.1186/14752867-13-44

78. Ravid Y, Formanski M, Smith Y, Reich R, Davidson B. Uterine Leiomyosarcoma and Endometrial Stromal Sarcoma Have Unique miRNA Signatures. Gynecol Oncol (2016) 140(3):512-7. doi: 10.1016/ j.ygyno.2016.01.001

79. Bavelloni A, Ramazzotti G, Poli A, Piazzi M, Focaccia E, Blalock W, et al. MiRNA-210: A Current Overview. Anticancer Res (2017) 37(12):6511-21. doi: 10.21873/anticanres.12107

80. Guo FJ, Shao YP, Wang YP, Jin YM, Liu SS, Wang QY. MIR-92 Stimulates VEGF by Inhibiting Von Hippel-Lindau Gene Product in Epithelial Ovarian Cancer. J Biol Regul Homeost Agents (2017) 31(3):615-24.

81. Wei J, Zhang L, Li J, Zhu S, Tai M, Mason CW, et al. MicroRNA-205 Promotes Cell Invasion by Repressing TCF21 in Human Ovarian Cancer. J Ovarian Res (2017) 10(1):33. doi: 10.1186/s13048-017-0328-1

82. Brodzikowska A, Gondek A, Rak B, Paskal W, Pelka K, CudnochJedrzejewska A, et al. Metalloproteinase 14 (MMP-14) and hsa-miR-410$3 p$ Expression in Human Inflamed Dental Pulp and Odontoblasts. Histochem Cell Biol (2019) 152(5):345-53. doi: 10.1007/s00418-019-01811-6

83. Deng J, Wang W, Yu G, Ma X. MicroRNA195 Inhibits Epithelialmesenchymal Transition by Targeting G Proteincoupled Estrogen Receptor 1 in Endometrial Carcinoma. Mol Med Rep (2019) 20 (5):4023-32. doi: 10.3892/mmr.2019.10652

84. Li S, Hu R, Wang C, Guo F, Li X, Wang S. miR-22 Inhibits Proliferation and Invasion in Estrogen Receptor Alpha-Positive Endometrial Endometrioid Carcinomas Cells. Mol Med Rep (2014) 9(6):2393-9. doi: 10.3892/ mmr.2014.2123

85. Zhang HH, Li R, Li YJ, Yu XX, Sun QN, Li AY, et al. Eif4erelated Mir320a and Mir3405p Inhibit Endometrial Carcinoma Cell Metastatic Capability by Preventing TGFbetalinduced Epithelialmesenchymal Transition. Oncol Rep (2020) 43(2):447-60. doi: 10.3892/or.2019.7437

86. Zhang P, Zhu J, Zheng Y, Zhang H, Sun H, Gao S. miRNA-574-3p Inhibits Metastasis and Chemoresistance of Epithelial Ovarian Cancer (EOC) by Negatively Regulating Epidermal Growth Factor Receptor (EGFR). Am J Transl Res (2019) 11(7):4151-65.

87. Wang H, Guan X, Tu Y, Zheng S, Long J, Li S, et al. MicroRNA-29b Attenuates non-Small Cell Lung Cancer Metastasis by Targeting Matrix Metalloproteinase 2 and PTEN. J Exp Clin Cancer Res (2015) 34:59. doi: 10.1186/s13046-015-0169-y

88. Li QH, Liu Y, Chen S, Zong ZH, Du YP, Sheng XJ, et al. Circ-CSPP1 Promotes Proliferation, Invasion and Migration of Ovarian Cancer Cells by Acting as a miR-1236-3p Sponge. BioMed Pharmacother (2019) 114:108832. doi: 10.1016/j.biopha.2019.108832 
89. Li N, Yang L, Sun Y, Wu X. MicroRNA-16 Inhibits Migration and Invasion via Regulation of the Wnt/beta-Catenin Signaling Pathway in Ovarian Cancer. Oncol Lett (2019) 17(3):2631-8. doi: 10.3892/ol.2019.9923

90. Chen YN, Ren CC, Yang L, Nai MM, Xu YM, Zhang F, et al. MicroRNA Let7d5p Rescues Ovarian Cancer Cell Apoptosis and Restores Chemosensitivity by Regulating the P53 Signaling Pathway via HMGA1. Int J Oncol (2019) 54(5):1771-84. doi: 10.3892/ijo.2019.4731

91. Gunel T, Gumusoglu E, Dogan B, Ertem FB, Hosseini MK, Cevik N, et al. Potential Biomarker of Circulating hsa-miR-1273g-3p Level for Detection of Recurrent Epithelial Ovarian Cancer. Arch Gynecol Obstet (2018) 298 (6):1173-80. doi: 10.1007/s00404-018-4913-3

92. Liu X, Yao B, Wu Z. miRNA-199a-5p Suppresses Proliferation and Invasion by Directly Targeting NF-Kappab1 in Human Ovarian Cancer Cells. Oncol Lett (2018) 16(4):4543-50. doi: 10.3892/ol.2018.9170

93. Huang X, Teng Y, Yang H, Ma J. Propofol Inhibits Invasion and Growth of Ovarian Cancer Cells via Regulating miR-9/NF-kappaB Signal. Braz J Med Biol Res (2016) 49(12):e5717. doi: 10.1590/1414-431X20165717

94. Duan Y, Dong Y, Dang R, Hu Z, Yang Y, Hu Y, et al. MiR-122 Inhibits Epithelial Mesenchymal Transition by Regulating P4HA1 in Ovarian Cancer Cells. Cell Biol Int (2018) 42(11):1564-74. doi: 10.1002/cbin.11052

95. Zhou D, Zhang L, Sun W, Guan W, Lin Q, Ren W, et al. Cytidine Monophosphate Kinase Is Inhibited by the TGF-Beta Signalling Pathway Through the Upregulation of miR-130b-3p in Human Epithelial Ovarian Cancer. Cell Signal (2017) 35:197-207. doi: 10.1016/j.cellsig.2017.04.009

96. Gong C, Yang Z, Wu F, Han L, Liu Y, Gong W. miR-17 Inhibits Ovarian Cancer Cell Peritoneal Metastasis by Targeting ITGA5 and ITGB1. Oncol Rep (2016) 36(4):2177-83. doi: 10.3892/or.2016.4985

97. Li P, Sun Y, Liu Q. MicroRNA-340 Induces Apoptosis and Inhibits Metastasis of Ovarian Cancer Cells by Inactivation of NF-X03ba;B1. Cell Physiol Biochem (2016) 38(5):1915-27. doi: 10.1159/000445553

98. Song N, Liu H, Ma X, Zhang S. Placental Growth Factor Promotes Metastases of Ovarian Cancer Through MiR-543-Regulated MMP7. Cell Physiol Biochem (2015) 37(3):1104-12. doi: 10.1159/000430235

99. Guo F, Tian J, Lin Y, Jin Y, Wang L, Cui M. Serum microRNA-92 Expression in Patients With Ovarian Epithelial Carcinoma. J Int Med Res (2013) 41 (5):1456-61. doi: 10.1177/0300060513487652

100. Zhang S, Zhou X, Wang B, Zhang K, Liu S, Yue K, et al. Loss of VHL Expression Contributes to Epithelial-Mesenchymal Transition in Oral Squamous Cell Carcinoma. Oral Oncol (2014) 50(9):809-17. doi: 10.1016/ j.oraloncology.2014.06.007

101. Choi SJ, Jung SW, Huh S, Chung YS, Cho H, Kang H. Alteration of DNA Methylation in Gastric Cancer With Chemotherapy. J Microbiol Biotechnol (2017) 27(8):1367-78. doi: 10.4014/jmb.1704.04035

102. Rodriguez AC, Blanchard Z, Maurer KA, Gertz J. Estrogen Signaling in Endometrial Cancer: A Key Oncogenic Pathway With Several Open Questions. Horm Cancer (2019) 10(2-3):51-63. doi: 10.1007/s12672-019-0358-9

103. Liu C, Hu W, Li LL, Wang YX, Zhou Q, Zhang F, et al. Roles of miR-200 Family Members in Lung Cancer: More Than Tumor Suppressors. Future Oncol (2018) 14(27):2875-86. doi: 10.2217/fon-2018-0155

104. Mekala JR, Naushad SM, Ponnusamy L, Arivazhagan G, Sakthiprasad V, PalBhadra M. Epigenetic Regulation of miR-200 as the Potential Strategy for the Therapy Against Triple-Negative Breast Cancer. Gene (2018) 641:248-58. doi: 10.1016/j.gene.2017.10.018

105. O’Brien SJ, Carter JV, Burton JF, Oxford BG, Schmidt MN, Hallion JC, et al. The Role of the miR-200 Family in Epithelial-Mesenchymal Transition in Colorectal Cancer: A Systematic Review. Int J Cancer (2018) 142(12):250111. doi: $10.1002 / \mathrm{ijc} .31282$

106. D’Ippolito E, Plantamura I, Bongiovanni L, Casalini P, Baroni S, Piovan C, et al. miR-9 and miR-200 Regulate PDGFRbeta-Mediated Endothelial Differentiation of Tumor Cells in Triple-Negative Breast Cancer. Cancer Res (2016) 76(18):5562-72. doi: 10.1158/0008-5472.CAN-16-0140

107. Yang X, Hu Q, Hu LX, Lin XR, Liu JQ, Lin X, et al. miR-200b Regulates Epithelial-Mesenchymal Transition of Chemo-Resistant Breast Cancer Cells by Targeting FN1. Discovery Med (2017) 24(131):75-85.

108. Ren S, Liu J, Feng Y, Li Z, He L, Li L, et al. Knockdown of Circdennd4c Inhibits Glycolysis, Migration and Invasion by Up-Regulating miR-200b/C in Breast Cancer Under Hypoxia. J Exp Clin Cancer Res (2019) 38(1):388. doi: 10.1186/s13046-019-1398-2
109. Izdebska M, Zielinska W, Grzanka D, Gagat M. The Role of Actin Dynamics and Actin-Binding Proteins Expression in Epithelial-To-Mesenchymal Transition and Its Association With Cancer Progression and Evaluation of Possible Therapeutic Targets. BioMed Res Int (2018) 2018:4578373. doi: $10.1155 / 2018 / 4578373$

110. Sugiyama K, Kajiyama H, Shibata K, Yuan H, Kikkawa F, Senga T. Expression of the Mir200 Family of microRNAs in Mesothelial Cells Suppresses the Dissemination of Ovarian Cancer Cells. Mol Cancer Ther (2014) 13(8):2081-91. doi: 10.1158/1535-7163.MCT-14-0135

111. Li S, Geng J, Xu X, Huang X, Leng D, Jiang D, et al. miR-130b-3p Modulates Epithelial-Mesenchymal Crosstalk in Lung Fibrosis by Targeting IGF-1. PloS One (2016) 11(3):e0150418. doi: 10.1371/journal.pone.0150418

112. Shui Y, Yu X, Duan R, Bao Q, Wu J, Yuan H, et al. miR-130b-3p Inhibits Cell Invasion and Migration by Targeting the Notch Ligand Delta-Like 1 in Breast Carcinoma. Gene (2017) 609:80-7. doi: 10.1016/j.gene.2017.01.036

113. Li M, Zheng R, Yuan FL. MiR-410 Affects the Proliferation and Apoptosis of Lung Cancer A549 Cells Through Regulation of SOCS3/JAK-STAT Signaling Pathway. Eur Rev Med Pharmacol Sci (2018) 22(18):5987-93. doi: 10.26355/eurrev_201809_15933

114. Yu X, Zhang Y, Wu B, Kurie JM, Pertsemlidis A. The miR-195 Axis Regulates Chemoresistance Through TUBB and Lung Cancer Progression Through BIRC5. Mol Ther Oncolytics (2019) 14:288-98. doi: 10.1016/ j.omto.2019.07.004

115. Gao X, Lu M, Xu W, Liu C, Wu J. miR-195 Inhibits Esophageal Cancer Cell Proliferation and Promotes Apoptosis by Downregulating YAP1. Int J Clin Exp Pathol (2019) 12(1):275-81.

116. Li B, Wang S, Wang S. MiR-195 Suppresses Colon Cancer Proliferation and Metastasis by Targeting WNT3A. Mol Genet Genomics (2018) 293(5):124553. doi: 10.1007/s00438-018-1457-y

117. Li WC, Wu YQ, Gao B, Wang CY, Zhang JJ. MiRNA-574-3p Inhibits Cell Progression by Directly Targeting CCND2 in Colorectal Cancer. Biosci Rep (2019) 39(12). doi: 10.1042/BSR20190976

118. Wang M, Zhang R, Zhang S, Xu R, Yang Q. MicroRNA-574-3p Regulates Epithelial Mesenchymal Transition and Cisplatin Resistance via Targeting ZEB1 in Human Gastric Carcinoma Cells. Gene (2019) 700:110-9. doi: 10.1016/j.gene.2019.03.043

119. Zhang X, Li Y, Qi P, Ma Z. Biology of MiR-17-92 Cluster and Its Progress in Lung Cancer. Int J Med Sci (2018) 15(13):1443-8. doi: 10.7150/ijms.27341

120. Jin J, Kim SN, Liu X, Zhang H, Zhang C, Seo JS, et al. miR-17-92 Cluster Regulates Adult Hippocampal Neurogenesis, Anxiety, and Depression. Cell Rep (2016) 16(6):1653-63. doi: 10.1016/j.celrep.2016.06.101

121. Mandelbaum AD, Kredo-Russo S, Aronowitz D, Myers N, Yanowski E, Klochendler A, et al. miR-17-92 and miR-106b-25 Clusters Regulate Beta Cell Mitotic Checkpoint and Insulin Secretion in Mice. Diabetologia (2019) 62(9):1653-66. doi: 10.1007/s00125-019-4916-Z

122. Liu X, Gan L, Zhang J. miR-543 Inhibites Cervical Cancer Growth and Metastasis by Targeting TRPM7. Chem Biol Interact (2019) 302:83-92. doi: 10.1016/j.cbi.2019.01.036

123. Zhao H, Diao C, Wang X, Xie Y, Liu Y, Gao X, et al. MiR-543 Promotes Migration, Invasion and Epithelial-Mesenchymal Transition of Esophageal Cancer Cells by Targeting Phospholipase A2 Group IVA. Cell Physiol Biochem (2018) 48(4):1595-604. doi: 10.1159/000492281

124. Zhai F, Cao C, Zhang L, Zhang J. miR-543 Promotes Colorectal Cancer Proliferation and Metastasis by Targeting KLF4. Oncotarget (2017) 8 (35):59246-56. doi: 10.18632/oncotarget.19495

125. Quemener C, Gabison EE, Naimi B, Lescaille G, Bougatef F, Podgorniak MP, et al. Extracellular Matrix Metalloproteinase Inducer Up-Regulates the Urokinase-Type Plasminogen Activator System Promoting Tumor Cell Invasion. Cancer Res (2007) 67(1):9-15. doi: 10.1158/0008-5472.CAN-062448

126. Mezyk-Kopec R, Wyroba B, Stalinska K, Prochnicki T, Wiatrowska K, Kilarski WW, et al. ADAM17 Promotes Motility, Invasion, and Sprouting of Lymphatic Endothelial Cells. PloS One (2015) 10(7):e0132661. doi: 10.1371/journal.pone.0132661

127. Furler RL, Nixon DF, Brantner CA, Popratiloff A, Uittenbogaart CH. TGFBeta Sustains Tumor Progression Through Biochemical and Mechanical Signal Transduction. Cancers (Basel) (2018) 10(6). doi: 10.3390/ cancers 10060199 
128. Smirnova T, Bonapace L, MacDonald G, Kondo S, Wyckoff J, Ebersbach H, et al. Serpin E2 Promotes Breast Cancer Metastasis by Remodeling the Tumor Matrix and Polarizing Tumor Associated Macrophages. Oncotarget (2016) 7(50):82289-304. doi: 10.18632/oncotarget.12927

129. Jia ZH, Jia Y, Guo FJ, Chen J, Zhang XW, Cui MH. Phosphorylation of STAT3 at Tyr705 Regulates MMP-9 Production in Epithelial Ovarian Cancer. PloS One (2017) 12(8):e0183622. doi: 10.1371/journal.pone.0183622

130. Peeney D, Jensen SM, Castro NP, Kumar S, Noonan S, Handler C, et al. TIMP-2 Suppresses Tumor Growth and Metastasis in Murine Model of Triple-Negative Breast Cancer. Carcinogenesis (2020) 41(3):313-25. doi: $10.1093 /$ carcin/bgz172

131. Park H, Huang X, Lu C, Cairo MS, Zhou X. MicroRNA-146a and microRNA-146b Regulate Human Dendritic Cell Apoptosis and Cytokine Production by Targeting TRAF6 and IRAK1 Proteins. J Biol Chem (2015) 290(5):2831-41. doi: 10.1074/jbc.M114.591420

132. Yu Y, Kanwar SS, Patel BB, Oh PS, Nautiyal J, Sarkar FH, et al. MicroRNA21 Induces Stemness by Downregulating Transforming Growth Factor Beta Receptor 2 (TGFbetaR2) in Colon Cancer Cells. Carcinogenesis (2012) 33 (1):68-76. doi: 10.1093/carcin/bgr246

133. Pan BL, Tong ZW, Li SD, Wu L, Liao JL, Yang YX, et al. Decreased microRNA-182-5p Helps Alendronate Promote Osteoblast Proliferation and Differentiation in Osteoporosis via the Rapl/MAPK Pathway. Biosci Rep (2018) 38(6). doi: 10.1042/BSR20180696

134. Tian Y, Liu Y, Wang T, Zhou N, Kong J, Chen L, et al. A microRNA-Hippo Pathway That Promotes Cardiomyocyte Proliferation and Cardiac Regeneration in Mice. Sci Transl Med (2015) 7(279):279ra38. doi: 10.1126/ scitranslmed.3010841

135. Rao DS, O'Connell RM, Chaudhuri AA, Garcia-Flores Y, Geiger TL, Baltimore D. MicroRNA-34a Perturbs B Lymphocyte Development by Repressing the Forkhead Box Transcription Factor Foxp1. Immunity (2010) 33(1):48-59. doi: 10.1016/j.immuni.2010.06.013

136. Mildner A, Chapnik E, Varol D, Aychek T, Lampl N, Rivkin N, et al. MicroRNA-142 Controls Thymocyte Proliferation. Eur J Immunol (2017) 47 (7):1142-52. doi: 10.1002/eji.201746987

137. Ghosh T, Soni K, Scaria V, Halimani M, Bhattacharjee C, Pillai B. MicroRNA-Mediated Up-Regulation of an Alternatively Polyadenylated Variant of the Mouse Cytoplasmic \{Beta\}-Actin Gene. Nucleic Acids Res (2008) 36(19):6318-32. doi: 10.1093/nar/gkn624

138. Han M, Dong LH, Zheng B, Shi JH, Wen JK, Cheng Y. Smooth Muscle 22 Alpha Maintains the Differentiated Phenotype of Vascular Smooth Muscle Cells by Inducing Filamentous Actin Bundling. Life Sci (2009) 84(1314):394-401. doi: 10.1016/j.lfs.2008.11.017

139. Shah MY, Ferrajoli A, Sood AK, Lopez-Berestein G, Calin GA. microRNA Therapeutics in Cancer - An Emerging Concept. EBioMedicine (2016) 12:34-42. doi: 10.1016/j.ebiom.2016.09.017

140. Bonneau E, Neveu B, Kostantin E, Tsongalis GJ, De Guire V. How Close are miRNAs From Clinical Practice? A Perspective on the Diagnostic and Therapeutic Market. EJIFCC (2019) 30(2):114-27.

141. Valoczi A, Hornyik C, Varga N, Burgyan J, Kauppinen S, Havelda Z. Sensitive and Specific Detection of microRNAs by Northern Blot Analysis Using LNA-Modified Oligonucleotide Probes. Nucleic Acids Res (2004) 32 (22):e175. doi: 10.1093/nar/gnh171

142. Kloosterman WP, Wienholds E, de Bruijn E, Kauppinen S, Plasterk RH. In Situ Detection of miRNAs in Animal Embryos Using LNA-Modified
Oligonucleotide Probes. Nat Methods (2006) 3(1):27-9. doi: 10.1038/ nmeth843

143. Neely LA, Patel S, Garver J, Gallo M, Hackett M, McLaughlin S, et al. A Single-Molecule Method for the Quantitation of microRNA Gene Expression. Nat Methods (2006) 3(1):41-6. doi: 10.1038/nmeth825

144. Hagiwara K, Kosaka N, Yoshioka Y, Takahashi RU, Takeshita F, Ochiya T. Stilbene Derivatives Promote Ago2-Dependent Tumour-Suppressive microRNA Activity. Sci Rep (2012) 2:314. doi: 10.1038/srep00314

145. Ankenbruck N, Kumbhare R, Naro Y, Thomas M, Gardner L, Emanuelson C, et al. Small Molecule Inhibition of microRNA-21 Expression Reduces Cell Viability and Microtumor Formation. Bioorg Med Chem (2019) 27 (16):3735-43. doi: 10.1016/j.bmc.2019.05.044

146. Takahashi RU, Prieto-Vila M, Kohama I, Ochiya T. Development of miRNA-Based Therapeutic Approaches for Cancer Patients. Cancer Sci (2019) 110(4):1140-7. doi: 10.1111/cas.13965

147. Nguyen DD, Chang S. Development of Novel Therapeutic Agents by Inhibition of Oncogenic MicroRNAs. Int J Mol Sci (2017) 19(1). doi: 10.3390/ijms 19010065

148. Zhang P, Wang L, Rodriguez-Aguayo C, Yuan Y, Debeb BG, Chen D, et al. miR-205 Acts as a Tumour Radiosensitizer by Targeting ZEB1 and Ubc13. Nat Commun (2014) 5:5671. doi: 10.1038/ncomms6671

149. Cortez MA, Ivan C, Valdecanas D, Wang X, Peltier HJ, Ye Y, et al. PDL1 Regulation by P53 via miR-34. J Natl Cancer Inst (2016) 108(1). doi: 10.1093/jnci/djv303

150. Winer A, Adams S, Mignatti P. Matrix Metalloproteinase Inhibitors in Cancer Therapy: Turning Past Failures Into Future Successes. Mol Cancer Ther (2018) 17(6):1147-55. doi: 10.1158/1535-7163.MCT-17-0646

151. Chakraborty C, Sharma AR, Sharma G, Lee SS. Therapeutic Advances of miRNAs: A Preclinical and Clinical Update. J Adv Res (2021) 28:127-38. doi: 10.1016/j.jare.2020.08.012

152. Chen Y, Gao DY, Huang L. In Vivo Delivery of miRNAs for Cancer Therapy: Challenges and Strategies. Adv Drug Deliv Rev (2015) 81:128-41. doi: 10.1016/j.addr.2014.05.009

153. Munoz JL, Bliss SA, Greco SJ, Ramkissoon SH, Ligon KL, Rameshwar P. Delivery of Functional Anti-miR-9 by Mesenchymal Stem Cell-Derived Exosomes to Glioblastoma Multiforme Cells Conferred Chemosensitivity. Mol Ther Nucleic Acids (2013) 2:e126. doi: 10.1038/mtna.2013.60

Conflict of Interest: The authors declare that the research was conducted in the absence of any commercial or financial relationships that could be construed as a potential conflict of interest.

Publisher's Note: All claims expressed in this article are solely those of the authors and do not necessarily represent those of their affiliated organizations, or those of the publisher, the editors and the reviewers. Any product that may be evaluated in this article, or claim that may be made by its manufacturer, is not guaranteed or endorsed by the publisher.

Copyright (c) 2022 Pandit, Begum, Saha, Srivastava and Swarnakar. This is an openaccess article distributed under the terms of the Creative Commons Attribution License (CC BY). The use, distribution or reproduction in other forums is permitted, provided the original author(s) and the copyright owner(s) are credited and that the original publication in this journal is cited, in accordance with accepted academic practice. No use, distribution or reproduction is permitted which does not comply with these terms. 